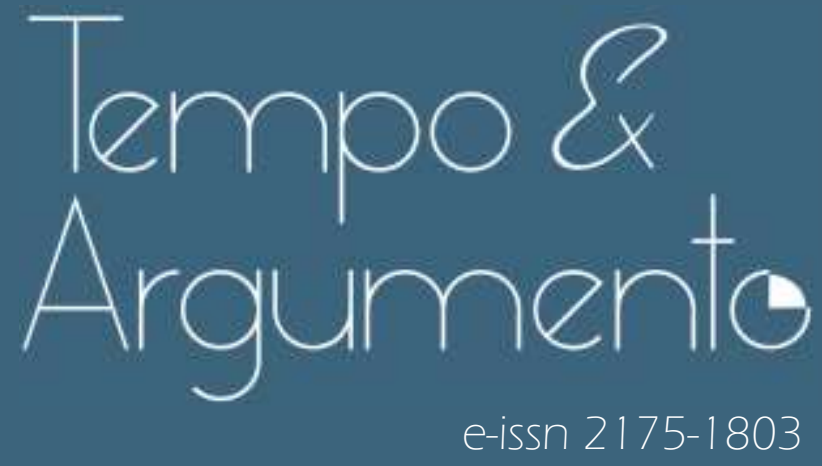

\title{
Os livros didáticos e a participação de mulheres na luta armada no Brasil
}

- Carla Simone Rodeghero

Doutora em História pela Universidade Federal do Rio Grande do Sul (UFRGS).

Professora do Programa de Pós-Graduação em História da Universidade

Federal do Rio Grande do Sul (PPGH/UFRGS).

Porto Alegre, RS - BRASIL

lattes.cnpq.br/9379089339600846

carlasimonerodeghero@gmail.com

(D) orcid.org/0000-0002-2669-726X

- Vanderlei Machado

Doutor em História pela Universidade Federal do Rio Grande do Sul (UFRGS).

Professor efetivo do Colégio de Aplicação da Universidade Federal do Rio Grande do SUl (UFRGS).

Porto Alegre, RS - BRASIL

lattes.cnpq.br/4087072904135000

vandermachado@hotmail.com

(D) orcid.org/0000-000 1-8353-7580

Para citar este artigo:

RODEGHERO, Carla Simone; MACHADO, Vanderlei. Os livros didáticos e a participação de mulheres na luta armada no Brasil. Tempo e Argumento,

Florianópolis, v. 13, n. 34, e0307, set./dez. 2021.

doi http://dx.doi.org/10.5965/2175180313342021 e0307

Recebido: 22/03/2021

Aprovado: 03/10/2021 


\title{
Os livros didáticos e a participação de mulheres na luta armada no Brasil
}

\begin{abstract}
Resumo
Este artigo analisa um conjunto de livros didáticos de História dos catálogos do Programa Nacional do Livro Didático para o Ensino Médio (PNLEM) de 2008 e de 2018, atentando para os modos como apresentam a participação de mulheres na luta armada no Brasil, entre 1968 e 1974. A razão de nos debruçarmos sobre o tema se justifica pelo lugar que a luta armada tem na história e na memória da ditadura brasileira, pela presença do tema nos livros analisados e, ainda, pela existência de pesquisas acadêmicas e publicações diversas sobre o protagonismo de mulheres nesses acontecimentos. O texto está organizado em três partes: na primeira, apresentamos o PNLEM, os livros didáticos a serem examinados e as resenhas feitas sobre eles nos Catálogos de 2008 e de 2018, como parte do processo de avaliação previsto no Programa; na segunda parte, exploramos os conteúdos dos livros selecionados; na terceira e última parte, dialogamos com a historiografia sobre mulheres na luta armada e sobre livro didático de História.
\end{abstract}

Palavras-chave: livros didáticos de história; mulheres; ditadura; luta armada.

\section{Textbooks and the women's participation in armed struggle in Brazil}

\begin{abstract}
This article analyzes a set of History textbooks from the catalogs of the National High School Textbook Program (PNLEM) of 2008 and 2018, with the aim to analyze the ways in which women's participation in the armed organizations in Brazil, between 1968 and 1974, is presented. The reason for focusing on the theme is justified by the place that the armed struggle has in the history and memory of the Brazilian dictatorship, by the presence of the theme in the selected school textbooks and, also, by the existence of research and publications on the women's participation in these events. The text is organized in three parts: in the first, we present the PNLEM, the textbooks to be examined and the reviews made about them in the 2008 and 2018 Catalogs, as part of the evaluation process provided for the Program; in the second part, we explore the contents of the selected books; in the third and last part, we dialogue with the historiography about women in armed struggle and about the history textbook.
\end{abstract}

Keywords: history textbooks; women; Brazilian dictatorship; armed struggle. 
Neste artigo, analisamos as maneiras como um conjunto de livros didáticos de História - do Programa Nacional do Livro Didático para o Ensino Médio (PNLEM) 2008 e 2018 - aborda a participação de mulheres nos grupos clandestinos de esquerda que pegaram em armas para combater a ditadura no Brasil. A reflexão faz parte de um projeto mais amplo intitulado "A História das mulheres que os livros didáticos não contam: as lutas femininas contra a ditadura militar no Brasil". O interesse pelo tema surgiu em 2008, ano marcado por uma série de eventos acadêmicos visando rememorar os acontecimentos de 1968, no Brasil e no mundo. Também em 2008, o governo federal, pela primeira vez, enviou os livros didáticos de História do Ensino Médio para as escolas públicas de todo o país, através do PNLEM. Os debates que ocorreram naquele ano emblemático, parte dos quais se referia ao contexto da decretação do Al-5 e à militância política contra a ditadura, tiveram repercussão na historiografia brasileira. Considerando que o diálogo entre a produção acadêmica e a cultura escolar é uma das possíveis variáveis para análise do conteúdo dos livros didáticos, nos interessamos por averiguar como os mesmos vinham apresentando a participação de mulheres na resistência e no enfrentamento ao regime.

Nos marcos desta pesquisa, já exploramos algumas formas de luta contra a ditadura nas quais houve participação de mulheres, como no movimento pela anistia (RODEGHERO; MACHADO, 2010), no movimento estudantil (MACHADO; RODEGHERO, 2017 e RODEGHERO; MACHADO, 2017) e nas buscas e denúncias de mães e pais de presos/as, de mortos/as e desaparecidos/as políticos/as (MACHADO, 2013). No presente artigo, analisaremos a atuação de mulheres em grupos clandestinos de esquerda que optaram pela luta armada. Além de descrever e analisar a maneira como os livros didáticos selecionados abordam ou silenciam sobre tais temáticas, a intenção do texto é indicar a existência de subsídios que podem ser aproveitados para o trabalho em sala de aula, com destaque para a produção historiográfica sobre o tema.

Em 2008, quando iniciamos o projeto de pesquisa, já existiam bibliografia (livros de memórias, trabalhos acadêmicos ou jornalísticos) e alguns filmes e

\footnotetext{
Ao longo do seu desenvolvimento, a pesquisa contou com a participação de bolsistas de Iniciação Científica, a quem deixamos o nosso agradecimento. Nos períodos mais recentes, tivermos a colaboração de Luísa Dornelles Briggmann (BIC/UFRGS/2015/16) e de Paula da Silva Ribeiro (BIC PRAE-2018/19).
} 
minisséries de televisão que abordavam a participação de mulheres em grupos clandestinos de esquerda². Essas produções, na sua maioria, se concentravam nas dimensões da tortura e da prisão a que determinadas mulheres foram submetidas, sem enfocar especificamente sua participação nas ações armadas. A partir daí, a historiografia sobre a ditadura ganhou forte impulso, tratando desses e de outros tipos de atuação política com forte presença de mulheres, como o movimento estudantil, as campanhas em prol da anistia, as lutas de familiares de pessoas desaparecidas e, é claro, o movimento feminista, todos temas que marcaram a década de $1970^{3}$.

Por conta disso, no andamento da pesquisa e no contato cotidiano com Livros didáticos de História, sempre nos intrigou a concomitância entre o vigor da produção acadêmica e a timidez da renovação dos conteúdos dos manuais escolares. Os anos que se seguiram a 2008 foram, também, ricos em políticas de memória relacionadas às heranças da ditadura, cujo auge foi o funcionamento da Comissão Nacional da Verdade (CNV), entre 2012 e 2014 (BRASIL, 2014a; BAUER, 2014). O capítulo 10 do Relatório Final da CNV, por exemplo, recebeu o título "Violência sexual, violência de gênero e violência contra crianças e adolescentes" e, nele, a violência contra as mulheres foi extensamente tratada (BRASIL, 2014b) .

Em artigo publicado no Brasil em 2002, Alain Choppin se questiona sobre os cuidados que os/as historiadores/as devem tomar ao transformar manuais escolares em objeto de estudo ${ }^{5}$. Trata-se de fontes ricas e complexas. Nas palavras do autor, é "fascinante - até mesmo inquietante - constatar que cada

\footnotetext{
Entre os trabalhos existentes, destacamos (COSTA, 1980; PATARRA, 1992; COLLING, 1994, 1997, 2004; FERREIRA, 1996; PAIVA, 1996; CARVALHO, 1998; SANTOS, 2003; VIANNA, 2003; RESENDE, 2006; DA-RIN, 2006). Também há subsídios no formato de documentário (MURAT, 1989) e minissérie de televisão (BRAGA, 1992). Para conhecer filmes produzidos mais recentemente sobre mulheres que lutaram contra a ditadura, ver: http://nodeoito.com/filmes-mulheresditadura-militar/.

3 Sem pretensão exaustiva, destacamos os seguintes trabalhos: DUARTE, 2009; TELES, 2009; CARBONI, 2008; VARGAS, 2010; PEDRO, WOLF, 2010; PEDRO, WOLF, VEIGA; 2011; RODEGHERO, DIENSTMANN, TRINDADE, 2011; SOUSA, 2011; INSUELA, 2011; ROVAI, 2013; PAULA, 2014; FAGUNDES, 2019; SILVA, 2019, BRIGGMANN, 2019.

${ }^{4}$ Sobre as particularidades e limites do trabalho da Comissão Nacional da Verdade no que se refere à violação dos direitos humanos das mulheres, ver SETEMY, 2020.

5 Em uma publicação mais recente, Choppin (2009) explora a diversidade de vocábulos utilizados para designar o manual escolar. Aqui, utilizaremos as expressões "livro didático", "livro escolar" e "manual escolar" como sinônimos.
} 
um de nós tem um olhar parcial ou parcializado sobre o manual" (CHOPPIN, 2002, p. 13). O manual ou livro escolar, na compreensão de Choppin, é depositário de um conteúdo educativo que foi selecionado para ser transmitido às novas gerações, em determinado contexto, em uma determinada área e como resultado de programas oficiais. É um material que "veicula (...) um sistema de valores morais, religiosos, políticos" e que participa, dessa maneira, da socialização da juventude (CHOPPIN, 2002, p. 14). E, ainda, é um objeto sujeito a limitações técnicas de sua época e que participa de um determinado sistema econômico (fabricação, difusão e consumo). Sua concepção e produção, no entanto, não esgotam as possibilidades de análise, as quais podem agregar seus usos em diferentes contextos.

A complexidade do objeto "livro didático" também é explorada por Erinaldo Cavalcanti (2016), especialmente no que se refere à noção de autoria ${ }^{6}$. Cavalcanti reflete sobre a complexidade dos procedimentos e a diversidade de profissionais que participam da produção do mesmo, sugerindo ser melhor falar em "autor de textos para livro didático”, do que em “autor de livro didático" (CAVALCANTI, 2016, p. 265). O autor destaca a importância de problematizar o processo de produção do livro, considerando condições de tempo e espaço assim como diferentes narrativas que o compõem, como a textual, a imagética, a gráfica. Ele também lembra das dimensões pedagógicas do livro didático e do processo de avaliação pelo qual cada obra passa antes de ser impressa e encaminhada às escolas. Alerta, dessa maneira, para o compartilhamento da responsabilidade pelo objeto "livro didático", a qual não fica circunscrita a quem escreve seus textos, mas engloba equipe de "pesquisa iconográfica, revisores, diagramadores, editores", o que torna o livro didático, "antes de tudo, filho de muitos pais e muitas mães" ( $p$. 269). Cavalcanti também lembra da triagem avaliativa promovida no âmbito do PNLD que envolve, entre outras coisas, a montagem de equipes para avaliação, a elaboração de resenhas dos livros selecionados e a sua publicação em catálogos. Considera, ainda, o uso criativo do material em sala de aula.

Esses e outros trabalhos com os quais dialogamos no presente artigo indicam que a análise histórica de livros didáticos e a análise sobre livros

\footnotetext{
${ }^{6}$ O tema da autoria dos livros didáticos também é explorado por Adriana Ralejo e Ana Maria Monteiro (2020).
} 
didáticos de história compartilham da percepção de que se trata de um tema complexo, contemplado por estudos sempre parciais e que, em sua complementaridade, permitem explorar políticas públicas, mercado editorial/autoria, usos dos livros, estratégias pedagógicas, diálogo com a ciência que lhes serve de referência, entre outras questões. Alain Choppin (2002, p. 15) já havia chamado a atenção para o fato de que análises seriais e estudos comparados são estratégias que ajudam a observar "a aparição e as transformações de uma noção científica, as inflexões de um método pedagógico ou as representações de um comportamento social”.

Reforçamos, então, que o presente artigo, sem desconsiderar as outras possibilidades elencadas, propõe um diálogo entre livros didáticos e a produção historiográfica a respeito do protagonismo de mulheres na luta armada contra a ditadura. O diálogo entre o conhecimento acadêmico e os livros didáticos (especialmente sobre mulheres e ditadura) já foi empreendido por outros/as autores/as, como será demonstrado adiante. Além disso, uma das pontes entre os dois universos é a presença de profissionais do ensino superior e da educação básica nas etapas avaliativas da política do Estado brasileiro para os livros didáticos, como é o caso do PNLEM. E há, finalmente, a inserção do autor e da autora do presente estudo na docência no ensino básico e no ensino superior e na pesquisa sobre o tema aqui explorado.

Mas antes de passarmos à exploração das fontes, vamos nos deter na relevância de estudar a forma como os livros didáticos do PNLEM 2008 e 2018 trataram do protagonismo de mulheres na luta armada, no contexto da ditadura. Iniciamos tomando emprestadas as palavras de Maria Paula Nascimento Araújo (2015) para caracterizar o fenômeno designado como "luta armada". Para a historiadora, "a luta armada foi uma ação extrema feita por grande parte da esquerda latino-americana entre as décadas de 1960 e 1970" (ARAÚJO, 2015, p. 245). Tal ação visava

responder a ditaduras e regimes de violência política. Inspirandose nas lutas de libertação colonial e no exemplo recente da vitória da Revolução Cubana, críticos ao que consideravam o imobilismo e o reformismo dos partidos comunistas mais tradicionais, grupos e organizações de esquerda dissidentes e/ou independentes optaram pela luta armada contra o capitalismo, os regimes de 
exploração e as ditaduras militares que se estabeleciam na América Latina. (ARAÚJO, 2015, p. 245-6)

A luta armada, no caso brasileiro, foi empreendida por uma miríade de organizações clandestinas, quase cinquenta, de acordo com o Brasil Nunca Mais (ARQUIDIOCESE DE SÃO PAULO, 1985, p. 89). Suas ações ganharam força após o Ato Institucional no 5 e compreenderam "tentativas de garantir recursos para as organizações sustentarem seus membros (...) e montarem uma estrutura para o treinamento militar (...); assaltos a bancos, que eram denominados como 'expropriações' (...); sequestro de diplomatas libertados em troca de presos políticos" e inclusive o "justiçamento" de companheiros e de agentes da ditadura (RODEGHERO, DIESNTMANN, GUAZZELLI, 2013, p. 83).

A experiência teve curta duração e foi desmantelada pelo regime, que utilizou a existência dos grupos "guerrilheiros" ou "terroristas" com uma das justificativas para o aumento da sua ação repressiva. A lista de pessoas mortas e desaparecidas durante a ditadura comporta uma significativa quantidade de militantes das organizações que optaram pela luta armada. Experiência radical e derrotada, a luta armada é, ainda hoje, "tema marcado por esquecimentos, acusações, ressentimentos, lembranças dolorosas" (ARAÚJO, 2015, p. 245). Tratase, portanto, de um tema sensível, de abordagem difícil, tanto na cultura acadêmica quanto na escolar. Como será explicitado adiante, o tema foi contemplado em todos os livros selecionados e, por essa razão, tornou-se possível analisar as formas como se deu sua apresentação.

Em pesquisa pioneira sobre os grupos clandestinos de esquerda durante a ditadura, Marcelo Ridenti (1990) contabilizou, a partir de mais de 700 processos que tramitaram no Superior Tribunal Militar, compilados no projeto Brasil Nunca Mais, que o percentual de mulheres entre a militância das organizações armadas urbanas foi de 18,3\%, valor considerado alto quando comparado com o do Partido Comunista Brasileiro, PCB, e das organizações nacionalistas, como o Movimento Nacional Revolucionário, MNR e o Movimento de Ação Revolucionária, MAR (RIDENTI, 1990, p. 113). Tratava-se, ainda segundo Ridenti (1990, p. 114), de uma participação "próxima do percentual de mulheres na composição da população economicamente ativa no Brasil em 1970, em torno de 21\%”. Além de explorar os 
processos do Projeto Brasil Nunca Mais, o pesquisador analisou depoimentos sobre a participação de mulheres nos grupos armados que tinham sido publicados dez anos antes, na obra Memórias das mulheres no exilio (COSTA et. al., 1980).

Ao analisar a militância de um conjunto de mulheres no contexto da ditadura, Elizabeth Xavier Ferreira (1996, p. 193) comenta que "a luta armada tornou-se a resposta radical dos setores de esquerda que se insurgiram contra o arbítrio. Assim, para enfrentar as forças do regime militar, as jovens militantes tiveram que romper com o seu mundo cotidiano e entrar para a clandestinidade". A isso se seguiu, ainda, de acordo com Ferreira (1996, p. 193), o desmantelamento das organizações clandestinas e o confinamento e/ou desaparecimento" dos/as seus/suas participantes. Segundo Ridenti (1990, p. 114), a participação "feminina nas esquerdas armadas era um avanço para a ruptura do estereótipo da mulher restrita ao espaço privado e doméstico, enquanto mãe, esposa, irmã e dona de casa, que vive em função do mundo masculino".

Assim, nos debruçarmos sobre a forma como um conjunto de livros didáticos tratou da participação de mulheres na luta armada pelos motivos que seguem: pelo lugar que a luta armada tem na história e na memória da ditadura brasileira, pela presença do tema nos manuais escolares analisados e, ainda, pela existência de pesquisas e publicações sobre o protagonismo de mulheres nesses acontecimentos. O texto está organizado em três partes: na primeira, apresentamos o PNLEM, os livros didáticos a serem examinados e as resenhas feitas sobre eles nos Catálogos de 2008 e de 2018, como parte do processo de avaliação previsto no Programa; na segunda parte, exploramos os conteúdos dos livros selecionados; na terceira e última parte, dialogamos com a historiografia sobre mulheres na luta armada e sobre livro didático de História.

\section{O Programa Nacional do Livro Didático para o Ensino Médio (PNLEM) e os guias/ catálogos de 2008 e 2018}

O PNLEM foi lançado em 2003. Segundo lara Augusta da Silva (2015), o programa foi instituído pelo Ministério da Educação, por meio da Resolução no 38, de 25 de outubro de 2003, como parte da política educacional de ampliação 
das ações voltadas para a distribuição de materiais didáticos aos estudantes da Educação Básica das escolas públicas. Até então, o Programa estava voltado ao Ensino Fundamental. Os livros didáticos das diferentes disciplinas do Ensino Médio foram sendo disponibilizados paulatinamente. Em 2005, o Programa contemplou os manuais de Língua Portuguesa e Matemática. Entre 2007, 2008 e 2009 foram incluídos, respectivamente, os livros de Biologia, História, Química, Geografia e Física (SILVA, 2015, p. 11). Foi a partir de 2008, então, que iniciou a distribuição gratuita dos livros didáticos de História do Ensino Médio. As séries finais do Ensino Fundamental recebiam os livros de História desde 1999.

Como explica Marcelo Soares Pereira da Silva (2017, p. 113), o Programa Nacional do Livro Didático (PNLD) foi instituído em 1985 pelo Decreto no 91.542 e começou a ser implementado no ano seguinte, consolidando políticas e práticas anteriores. Novidades foram sendo introduzidas, como a destinação de recursos para a compra de livros para as escolas públicas, a partir de 1993, e o início da avaliação pedagógica por especialistas em meados dos anos 1990. Segundo o autor (SILVA, 2017, p. 113), consolidou-se uma metodologia com os seguintes passos: 1) o edital é divulgado com a definição de "critérios, requisitos, especificações técnicas e vários outros aspectos a serem observados nos livros didáticos"; 2) as editoras inscrevem as obras a serem avaliadas; 3) as obras passam por "um processo de triagem e pré-análise" para verificação de "aspectos quanto à qualidade técnica da publicação"; 4) aquelas obras que atendem os requisitos do edital são "encaminhadas para a avaliação pedagógica por parte de comissões de especialistas"; 5) essa avaliação é a base para a elaboração pelo MEC do Guia de Livros Didáticos; 6) nas escolas, o Guia ou Catálogo subsidia a escolha do livro a ser adotado, de acordo com a área de conhecimento e a série; 7) com base nessa escolha, O MEC adquire as obras junto às editoras e as encaminha às escolas.

O Decreto no 7.084 de 2010, que tratou dos programas de material didático do MEC, incluindo o PNLD, trouxe algumas novidades, mas não mudou a metodologia acima descrita, ainda de acordo com a análise de Silva (2017). A partir do decreto, passou-se a exigir um detalhamento maior nos pareceres da equipe avaliadora; foi incluída a possibilidade de autores, autoras e editoras de 
obras reprovadas apresentarem recursos; foram contemplados materiais em formatos acessíveis para o público da educação especial; foi iniciado o atendimento a novas áreas do conhecimento para o Ensino Médio, como Filosofia, Sociologia, Língua Estrangeira e foi incentivada a incorporação de novas tecnologias.

Os livros didáticos distribuídos pelo PNLD passam por um processo de avaliação sistemática. Paulo Knauss (2009) estudou a evolução dos critérios de avaliação, destacando que no final da década de 1990 estava fixada a "tríade da reprovação", para os livros didáticos que não contemplassem "correção dos conceitos e informações básicas", "respeito à construção da cidadania e o combate aos preconceitos" e "coerência e adequação metodológica" (KNAUSS, 2009, p. 299). A partir do exame dos livros encaminhados para a avaliação do PNLEM de 2008, o autor conclui que "a marca dos livros didáticos do Ensino Médio no Brasil ainda é o caráter informativo enciclopédico” (KNAUSS, 2009, p. 307). Comparados aos livros mais antigos, aqueles da edição de 2008, ainda segundo Knauss, incorporaram "acréscimos pontuais que procuraram aprofundar dimensões da prática didática em relação aos livros, sem perder, porém, o caráter de justaposição" (KNAUSS, 2009, p. 307). Mais recentemente, Flávia Caimi fez um balanço sobre a avaliação dos manuais de História incluídos no PNLD, reconhecendo que o processo tem contribuído para "minimizar erros conceituais, anacronismos, simplificações explicativas, entre outras fragilidades dessa natureza que permeavam os livros didáticos antes" da implementação de tal dinâmica (CAIMI, 2017, p. 41).

Ao explorar de forma comparativa livros do PNLEM 2008 e 2018, tratando do tema da participação de mulheres na luta armada contra a ditadura, pretendemos reconhecer a aplicação dos critérios norteadores da avaliação prévia dos livros, como comentado no texto de Knauss (2009); contribuir para identificar, entender e superar simplificações e fragilidades, como indicado por Caimi (2017); e, ainda, auxiliar colegas docentes nos seus desafios de sala de aula ao apresentar subsídios sobre o tema em questão. Dialogaremos, também, com o artigo de Cristiane Bereta da Silva (2007), que explorou o tratamento dado (ou não dado) à história das mulheres e às relações de gênero nos livros didáticos 
de História do final dos anos 1980 ao momento da escrita e, também, com a análise de Helenice Rocha (2017) a respeito das narrativas sobre a ditadura presentes nos livros contemplados no PNLD 2011, e que teve como um dos seus focos o tratamento dado à participação da sociedade civil durante da ditadura.

Do recorte empírico de partida (19 livros de História indicados no PNLEM/2008 e 13 no PNLEM/2018), chegamos ao número de quatro títulos que estiveram presentes em ambos os catálogos (totalizando oito obras), com a intenção de avaliar continuidades e descontinuidades, passada uma década, na forma como o tema em questão foi abordado. Nossa análise se concentrou nos exemplares denominados como "livro do professor". ${ }^{7}$ Estes são distribuídos pelas editoras com a finalidade de auxiliar na escolha a ser feita pelas escolas. Os livros selecionados foram publicados por cinco diferentes editoras e são apresentados abaixo ${ }^{8}$ :

\section{Quadro 1 - Livros didáticos selecionados para análise}

\begin{tabular}{|c|c|}
\hline PNLDEM 2008 & PNLDEM 2018 \\
\hline $\begin{array}{l}\text { BRAICK, Patrícia Ramos e MOTA, Myriam } \\
\text { Becho. História das cavernas ao terceiro } \\
\text { milênio. São Paulo: Moderna, 1a ed., } \\
\text { 2005, vol. 3. }\end{array}$ & $\begin{array}{l}\text { BRAICK, Patrícia Ramos e MOTA, Myriam } \\
\text { Becho. História das cavernas ao terceiro } \\
\text { milênio. São Paulo: Moderna, 4ạ ed., } \\
\text { 2016, vol. 3. }\end{array}$ \\
\hline $\begin{array}{l}\text { COTRIM, Gilberto. História Global: Brasil } \\
\text { e Geral. São Paulo: Saraiva, 1a ed., 2005, } \\
\text { vol. único. }\end{array}$ & $\begin{array}{l}\text { COTRIM, Gilberto. História Global. São } \\
\text { Paulo: Saraiva, 3a ed., 2016, vol. } 3 .\end{array}$ \\
\hline $\begin{array}{l}\text { CAMPOS, Flávio e MIRANDA, Renan } \\
\text { Garcia. A escrita da história. São Paulo: } \\
\text { Escala Educacional, 1a ed., 2005, vol. } \\
\text { único. }\end{array}$ & $\begin{array}{l}\text { CAMPOS, Flávio de; PINTO, Júlio } \\
\text { Pimentel de; CLARO, Regina. Oficina de } \\
\text { História, São Paulo: Leya, 2a ed. 2016, vol. } \\
3\end{array}$ \\
\hline $\begin{array}{l}\text { AZEVEDO, Reinaldo e SERIACOPI, } \\
\text { Gislaine. História. São Paulo: Ática, 1a ed., } \\
\text { 2005, vol. único. }\end{array}$ & $\begin{array}{l}\text { AZEVEDO, Reinaldo e SERIACOPI, } \\
\text { Gislaine. História passado e presente. } \\
\text { São Paulo: Ática, 1a ed., 2016, vol. } 3 .\end{array}$ \\
\hline
\end{tabular}

O Livro do Professor é composto pelo Livro do Aluno e por outro material que recebe diferentes denominações e que tem como objetivo apresentar para os professores as opções teóricometodológicas do texto bem como orientações de como utilizá-lo em sala de aula.

${ }^{3}$ O número da edição e o ano da publicação considerados para este artigo são os indicados nas resenhas do Guia do PNLEM 2008 e 2018. Encontramos divergência entre essas informações e aquelas que constam nas folhas de rosto e nas fichas catalográficas de parte dos livros. 
O conteúdo que nos interessa analisar neste artigo é abordado nos subtítulos relativos ao período que vai da publicação do Ato Institucional n. 5 (Al5), em 13 de dezembro de 1968, até o início de 1974. Assim, concentramos nossa atenção nos tópicos que tratam dos governos dos generais Costa e Silva e Médici, encerrando nosso recorte na posse de Geisel, em março de 1974. Trata-se do período em que aconteceram as ações armadas contra o regime, as quais foram impulsionadas pelo fechamento político de 1968 e definitivamente encerradas com a derrota da Guerrilha do Araguaia, em 1973. É, ainda, o período conhecido como os "anos de chumbo", auge da repressão política.

Nos trechos que tratavam do período delimitado, buscamos indícios da presença de mulheres nos textos, boxes, imagens que tratam de grupos clandestinos de esquerda e da opção pelas armas, naqueles que explicam o funcionamento dos órgãos de repressão e nos que narram as situações de prisão e tortura. A metodologia de trabalho comportou a elaboração e preenchimento de uma ficha técnica (temas tratados, protagonistas destacadas, escolha de imagens, leituras recomendadas, bibliografia citada, articulação com outros temas do mesmo período etc.), a comparação entre as obras dos/as mesmos/as autores/as e editoras em edições diferentes, a comparação entre obras de diferentes autores/as e editoras no mesmo PNLEM e a atenção tanto aos temas tratados quanto às ausências.

Além disso, observamos as resenhas que constam no Catálogo do PNLEM/2008 (BRASIL, 2008) e no Guia do PNLEM/2018 (BRASIL, 2018). Nosso estudo compartilha da ideia de Cavalcanti (2016, p. 272) a respeito da importância de problematizarmos "os critérios de avaliação e seleção das equipes que avaliam e selecionam os livros que entrarão no Guia”. Por conta disso, consideramos válido iniciar a apresentação da pesquisa empírica com um breve balanço das resenhas publicadas nos guias do PNLDEM 2008 e 2018 sobre os oito livros selecionados. Esse será um dos parâmetros de análise do que encontramos nos livros didáticos sobre o tema que nos interessa, ou seja, a participação de mulheres na luta armada contra a ditadura.

Com relação ao manual História - das cavernas ao terceiro milênio (BRAICK; MOTA, 2005), a resenha de 2008 informa que ele "incorpora algumas 
temáticas renovadas, como a questão de gênero e temas relacionados aos fundamentalismos atuais, que têm implicado conflitos étnicos e religiosos". Também destaca que ao "analisar as formas históricas de relações sociais, a obra abre espaço para a incorporação dos objetos atuais da historiografia, como a vida cotidiana, a história das mulheres e a história das práticas alimentares" (BRASIL, 2008, p. 58, grifos nossos). Já a resenha da edição seguinte (BRAICK; MOTA, 2016) explica que a obra proporciona um "debate sobre os aspectos contemporâneos da superação de toda forma de violência, em especial a que se faz contra a mulher (...) e outras minorias ao longo da história", as quais "são apresentadas como protagonistas dos acontecimentos e processos históricos" (BRASIL, 2018, p. 91). A presença da história das mulheres, então, reconhecida na resenha sobre a edição de 2005, teria se mantido na de 2016.

No caso de A escrita da história (CAMPOS; MIRANDA, 2005), volume único, a resenha (BRASIL, 2008, p. 21-5) não destaca nenhum tratamento do tema "mulheres" ou "relações de gênero". Quanto à edição seguinte, versão em três volumes, que passa a ser intitulada Oficina de história (CAMPOS; PINTO; CLARO, 2016), lê-se na resenha que na obra "desenvolve-se concepção ampla de sujeitos históricos, agregando afro-brasileiros, mulheres, religiosos, trabalhadores, indígenas, entre outros (...). Nota-se o cuidado na abordagem do papel das mulheres em diferentes contextos históricos, das questões de gênero e das transformações na família” (BRASIL, 2018, p. 79-80, grifos nossos). Também é dito que a obra debate e incentiva "práticas pedagógicas democráticas de respeito ao outro, com ênfase para as relações de gênero" (BRASIL, 2018, p. 79-80, grifos nossos). Na comparação com o que foi registrado na resenha publicada no guia anterior, então, teria havido um avanço entre as duas edições do livro didático em relação à maneira como as mulheres são apresentadas.

Sobre o livro História (AZEVEDO; SERIACOPI, 2005), a resenha de 2008 reconhece "o esforço em incorporar a renovação historiográfica, valorizando-se abordagens, temas e objetos como a história do cotidiano, do consumo, das mulheres, das crianças" (BRASIL, 2018, p. 47, grifos nossos). No que se refere à edição seguinte (AZEVEDO; SERIACOPI, 2016), a resenha de 2018 registra que a "participação das mulheres de diferentes classes e etnias, em diversos contextos 
e espaços sociais, é destacada na abordagem dos conteúdos históricos, por meio de textos em boxes, legendas das imagens, atividades que propõem discussões e pesquisas sobre a temática no passado e no presente" (BRASIL, 2018, p. 26, grifo nosso). Também foi registrado que atividades e ilustrações "abordam questões atuais da condição de gênero" e que a obra possui textos que contemplam "a violência contra mulheres e a população LGBTI" (BRASIL, 2018, p. 26, grifos nossos). Nas duas edições, então, a avaliação sobre a presença "das mulheres" é positiva, acompanhando a "renovação historiográfica".

Quanto à História Global (COTRIM, 2005; 2016), as resenhas (BRASIL, 2008, p. 76-80; BRASIL, 2018, p. 34-37) não mencionam "mulheres", "história das mulheres" ou "relações de gênero" entre os conteúdos/abordagens contemplados nas duas edições. A resenha de 2008 destaca que o texto do livro comporta uma "narrativa factual, linear e pouco dialógica" e que "alguns capítulos dão grande destaque à atuação de líderes políticos, muito em função da opção por uma narrativa política e factual (BRASIL, 2008, p. 78-9). Na resenha do Guia de 2018, não se repete essa observação crítica. Nosso primeiro impulso, ao ler as resenhas sobre esse manual foi o de excluí-lo do corpus documental do artigo. Porém, como demonstraremos adiante, nos manuais para os quais as resenhas indicaram a presença de "mulheres", "história das mulheres" ou "relações de gênero", isso não necessariamente é abordado nos textos que se referem ao nosso recorte temático, no caso, a presença de mulheres na luta armada contra a ditadura.

Na sistematização das resenhas, optamos por grifar algumas expressões usadas para identificar proximidades dos conteúdos com o tema da presente pesquisa. Encontramos as palavras/expressões que seguem: a mulher, mulheres, história das mulheres, papel das mulheres, participação das mulheres, questões de gênero, condições de gênero, relações de gênero. Uma análise desse conjunto de expressões poderia ser realizada a partir de um cotejamento com a produção acadêmica e seus desdobramentos ao longo das últimas três décadas e em especial no período entre o PNLEM 2008 e o 2018, mas isso não está no escopo deste artigo. 
Ainda assim, é importante registrar que alguns trabalhos que se debruçam sobre a constituição desse campo de estudos permitem entender três grandes movimentos: 1) a emergência da história das mulheres na década de 1970, que iniciou o questionamento do lugar das mulheres no processo histórico; 2) a introdução da categoria gênero de análise histórica no final dos anos 1980, a qual contribuiu para o entendimento das diferenças entre os sexos como construção cultural e histórica, para a crítica aos conceitos essencialistas de mulher e de homem e para o enfoque de relações, hierarquias e poderes; 3) a tensão e a articulação entre as duas abordagens mencionadas, desde o final do século XX e com as teorias queer e decoloniais, mais recentemente, o que têm possibilitado, entre outras coisas, repensar o conceito de mulher e articular gênero a outros marcadores como classe e raça (SOHIET; PEDRO, 2007, MATOS, 2013; VAQUINHAS, 2015; PEDRO E VEIGA, 2015).

Considerando a complexidade e a riqueza desse campo, o que encontramos nas resenhas analisadas foi a mescla e a imprecisão de conceitos. Além disso, quando fomos aos livros didáticos buscar as narrativas que contemplassem tais conceitos/ abordagens/ objetos encontramos poucos registros, como será demonstrado no próximo tópico. Dessa forma, nosso esforço acabou se dirigindo para um dos objetivos que marcou a nascente história das mulheres: mostrar que o processo histórico "luta armada contra a ditadura" contou com a participação de mulheres. Tomamos o cuidado de não essencializar o conceito "mulher" e de dialogar com uma bibliografia que permite a aproximação a um conjunto de mulheres, socialmente situadas, que participou de tal experiência histórica.

\section{Mulheres na luta armada: o protagonismo ausente}

O propósito deste tópico é sistematizar como os livros selecionados apresentam a opção pela luta armada, a constituição dos grupos clandestinos e as suas ações. E, nesse quadro, averiguar situações nas quais aparecem mulheres. Lembramos que o tema da luta armada foi contemplado em todos os livros analisados, indicando que essa temática foi considerada relevante para o entendimento do período que o Brasil viveu sob uma ditadura. Ou, seja, o olhar 
inquiridor que estamos dirigindo aos livros se baseia nessa premissa: os autores, as autoras, as editoras, ou seja, o conjunto das pessoas que estiveram envolvidas na produção dos livros selecionados, optaram em tratar do tema da luta armada nos volumes dirigidos ao Ensino Médio. Ao abordá-lo, no entanto, fizeram algumas escolhas que procuraremos elucidar por meio de um olhar atento e comparativo e considerando que a presença de mulheres nos grupos guerrilheiros foi constatada em livros de memória, documentários e pesquisas acadêmicas há bastante tempo e reforçada em estudos recentes. Alain Choppin lembra que, por questões pedagógicas, os livros tendem à esquematização, sendo necessariamente redutores. Nesse quadro, as escolhas dos seus idealizadores (no que se refere aos fatos e à sua apresentação) "não são neutras e os silêncios são também bem reveladores" (CHOPPIN, 2002, p. 22), como pretendemos sustentar a partir da análise que segue.

A emergência da luta armada, conforme os livros analisados, ocorre após a publicação do Ato Institucional n. 5, pelo governo Costa e Silva, em dezembro de 1968. No livro História das cavernas ao terceiro milênio (BRAICK; MOTA, 2005), a publicação do Al-5 aparece como uma reposta do governo ao fato de a Câmara dos Deputados ter rejeitado o pedido para que fosse suspensa a imunidade parlamentar de Márcio Moreira Alves, visando a abertura de processo contra ele. O livro analisado reproduz um trecho do discurso proferido pelo deputado em 03 de setembro de 1968. Ali há duas menções a mulheres (mães de estudantes e namoradas de cadetes e de jovens oficiais):

seria necessário que cada pai e cada mãe, se compenetrasse que a presença de seus filhos nesse desfile é um auxílio aos carrascos que os espancam e metralham nas ruas. Portanto, que cada um boicote esse desfile. Esse boicote pode passar também - sempre falando de mulheres - às moças que dançam com cadetes e namoram os jovens oficiais. Seria preciso fazer hoje no Brasil com que as mulheres de 1968 repetissem as paulistas da Guerra dos Emboabas e recusassem a entrada à porta de suas casas àqueles que vilipendiam a Nação, recusassem aqueles que silenciam e, portanto, se acumpliciam. Discordar em silêncio, pouco adianta (BRAICK; MOTA, 2005, p. 160, grifos nossos).

Na fala do deputado, as mulheres são conclamadas a agir em relação aos homens que governam o país a partir da esfera do privado. No discurso reconhece-se o espaço de atuação feminina como restrito ao lar. E é a partir do 
espaço privado, segundo o deputado, que as mulheres deveriam influenciar os homens que atuam na esfera pública política. O discurso de Márcio Moreira Alves não levou em conta que naquele ano de 1968, nas grandes manifestações de rua, por exemplo, as mulheres, estudantes, artistas, religiosas, mães, entre outras, tomaram o espaço público se manifestando contra a ditadura e as violências cometidas pela repressão, como aconteceu na Marcha dos 100 mil, em junho daquele ano. Na edição de 2016 (BRAICK; MOTA, 2016, p. 173), o trecho do discurso de Márcio Moreira Alves foi suprimido e a informação foi assim resumida: "para agravar a situação, o deputado Márcio Moreira Alves do MDB convocou a população a boicotar a comemoração do 7 de setembro". A menção às mulheres desapareceu, bem como a referência ao poder que tinham de influenciar as decisões masculinas a partir de relações consideradas da esfera do privado? .

Ainda no livro de Braick e Mota (2005, p. 161), o início da luta armada, durante o governo Costa e Silva, é explicado pela "falta de crédito na ação parlamentar, que se mostrava incapaz de barrar o avanço da ditadura", o que "levou setores da esquerda brasileira a se lançar em ações guerrilheiras visando à derrubada do regime". Na edição de 2016, a relação entre o descrédito na "ação parlamentar" e a opção em "se lançar em ações guerrilheiras" foi retirada. Por outro lado, as autoras argumentam que "as manifestações públicas e o movimento estudantil não tinham mais lugar no Brasil do Al-5. A voz das ruas era silenciada e o espaço institucional de resistência ao regime praticamente se esgotou" (BRAICK; MOTA, 2016, p. 174). A luta armada, segundo essas explicações, resultou das ações tomadas por coletivos como parlamentares e esquerda e pela impossibilidade das manifestações públicas e da atuação do movimento estudantil, que representavam a voz das ruas. Assim, sem poder se manifestar, parte da oposição, aderiu à luta armada. É importante lembrar a presença de mulheres nas manifestações de 1968, especialmente as do Rio de Janeiro, e a participação significativa de mulheres no movimento estudantil até ○ Al-5 (RODEGHERO; MACHADO, 2017). No livro analisado, no entanto, as autoras não consideraram importante deixar explícita a presença de mulheres nesse processo.

\footnotetext{
- Seis dos livros analisados mencionam o discurso de Márcio Moreira Alves. O tema não é comtemplado nas duas edições de Azevedo e Seriacopi (2005 e 2016).
} 
A mesma linha de raciocínio é adotada em A escrita da história (CAMPOS; MIRANDA, 2005, p. 590) e em Oficina da história (CAMPOS; PINTO; CLARO, 2016, p. 196). O texto que consta nas duas edições, apesar dos títulos e de alguns autores diferentes, é o mesmo e está reproduzido abaixo:

eliminada a possibilidade de oposição legal e de resistência civil, começou a ganhar corpo a menção do confronto militar. Muitos grupos de esquerda, compostos em sua maioria por estudantes e intelectuais, passaram a organizar a luta armada como instrumento de oposição à ditadura. Entusiasmados com os sucessos revolucionários chinês e cubano, grupos guerrilheiros desejavam estabelecer uma república socialista no Brasil. (CAMPOS; MIRANDA, 2005, p. 590; CAMPOS; PINTO; CLARO, 2016, p. 196, grifos nossos)

As palavras "estudantes e intelectuais", apelando ao masculino genérico, invisibilizam a participação de mulheres nos grupos de esquerda que optaram pela luta armada.

Na obra História Global, de Gilberto Cotrim, (2005, p. 561; 2016, p. 243), é destacada a perseguição instaurada após o Al-5. Em ambas as edições, consta que "o Al-5 conferia ao presidente da República amplos poderes para perseguir e reprimir as oposições" e que "utilizando o Al-5, o governo Costa e Silva determinou a prisão de milhares de pessoas em todo o país” (COTRIM, 2005, p. 561; 2016, p. 243). O uso do substantivo "pessoas" contorna a recorrente apresentação de sujeitos no masculino, mas, ao mesmo tempo, esconde a existência de muitos casos de prisões de mulheres que faziam oposição ao regime. Na edição de 2016, Cotrim apresenta um excerto do Brasil Nunca Mais que diz que "mulheres grávidas tiveram seus filhos abortados, esposas sofreram para incriminar seus maridos" (COTRIM, 2016, p. 244). Trata-se de referências indiretas às mulheres que foram presas. De maneira próxima ao que vimos no discurso de Márcio Moreira Alves, aqui, o sofrimento das mulheres está diretamente vinculado aos laços com filhos e maridos ${ }^{10}$.

A primeira edição de História (AZEVEDO; SERIACOPI, 2005) é marcada pela ausência de mulheres nos textos que tratam dos temas em questão. Porém, há

\footnotetext{
0 uso de depoimentos de mulheres, retirados do Brasil Nunca Mais, pelos livros analisados, merece um estudo à parte. Lembramos que em artigo tratando do PNLD 2011, Helenice Rocha (2017, p. 265) encontrou cinco obras, entre as 13 listadas no Programa, que utilizavam esse livro.
} 
uma alteração na edição de 2016 (AZEVEDO; SERIACOPI, 2016), como se pode ver no quadro comparativo abaixo:

"um grande número de jovens, muitos dos quais sob a liderança de dissidentes do Partido Comunista Brasileiro, decidiram deixar de lado os protestos pacíficos e partir para a luta armada. Surgiram assim grupos guerrilheiros que tentavam derrubar o governo por meio das armas, como explica o boxe abaixo" (AZEVEDO, SERIACOPI, 2005, p. 482). "um grande número de jovens, muitos dos quais sob a liderança de dissidentes do Partido Comunista Brasileiro (PCB), decidiram deixar de lado os protestos pacíficos e partir para a luta armada. Surgiram, assim, grupos guerrilheiros, com aproximadamente quinhentos combatentes, entre homens e mulheres, que tentavam derrubar o governo com ataques como assaltos, atentados, sequestros etc." (AZEVEDO, SERIACOPI, 2016, p. 190, grifos nossos)

Assim, ao caracterizar "combatentes" como "homens e mulheres", temos na edição de 2016 do livro de Azevedo e de Seriacopi uma menção direta à presença de mulheres na luta armada. Na página seguinte, há um texto sobre a repressão, no qual é usada novamente a expressão "entre homens e mulheres", para tratar de pessoas mortas e desaparecidas durante o regime. É interessante registrar que nesse trecho o número de vítimas foi atualizado em relação ao que constava na edição anterior e que a fonte das informações mudou: na edição de 2005, era o livro Brasil Nunca Mais e na de 2016, a Comissão Especial de Mortos e Desaparecidos. Isso indica uma recepção das políticas de Estado relativas à herança da ditadura. A mesma Comissão serve de base ao boxe intitulado "Passado presente: nas garras da ditadura", que trata dos números da repressão contra a oposição, apresentando o perfil de cinco pessoas mortas ou desaparecidas. Entre elas estão Maria Lúcia Petit da Silva, "professora primária, integrante do PCdoB, militava na Guerrilha do Araguaia quando foi morta" e Esmeraldina Carvalho Cunha, que foi encontrada morta em sua casa em Salvador - numa simulação de suicídio - depois de ter denunciado que os órgãos da ditadura haviam assassinado sua filha, Nilda Carvalho Cunha, de 17 anos (AZEVEDO, SERIACOPI, 2016, p. 192). O Relatório Final da Comissão Nacional da Verdade (BRASIL, 2014c, vol. 3, p. 771 e 1064) trata dos dois casos e esclarece que 
Nilda fazia parte do MR-8, uma organização que optou pela luta armada. Ou seja, na edição de 2016 do livro de Azevedo e Seriacopi encontramos mais alguns indícios da presença de mulheres na luta armada, ainda que em textos que tratavam da repressão.

Visualizemos, agora, um quadro comparativo que mostra como os manuais retrataram as ações da luta armada.

\section{Quadro 2 - Tópicos sobre a luta armada nos livros analisados}

\begin{tabular}{|c|c|c|c|c|c|c|c|c|}
\hline $\begin{array}{l}\text { Autores/as } \\
\text { e/edições } \\
\text { Temas }\end{array}$ & $\begin{array}{l}\text { BRAICK; } \\
\text { MOTA, } \\
2005\end{array}$ & $\begin{array}{l}\text { BRAICK; } \\
\text { MOTA, } \\
2016\end{array}$ & $\begin{array}{l}\text { CAMPOS; } \\
\text { MIRANDA, } \\
2005\end{array}$ & $\begin{array}{l}\text { CAMPOS; } \\
\text { PINTO; } \\
\text { CLARO; } \\
2016\end{array}$ & $\begin{array}{l}\text { COTRIM, } \\
2005\end{array}$ & $\begin{array}{l}\text { COTRIM, } \\
2016\end{array}$ & $\begin{array}{l}\text { AZEVEDO; } \\
\text { SERIACOPI, } \\
2005\end{array}$ & $\begin{array}{l}\text { AZEVEDO; } \\
\text { SERIACOPI, } \\
2016\end{array}$ \\
\hline Assaltos & & & $\bar{x}$ & $x$ & $x$ & $x$ & $\bar{x}$ & $\bar{x}$ \\
\hline $\begin{array}{l}\text { Sequestros } \\
\text { de } \\
\text { diplomatas } \\
\text { e trocas } \\
\text { por presos } \\
\text { políticos }\end{array}$ & $x$ & & $x$ & $x$ & $x$ & $x$ & $x$ & $x$ \\
\hline Marighella & $X^{11}$ & $x$ & $x$ & $x$ & $x$ & $x$ & $x$ & \\
\hline Lamarca & $x$ & 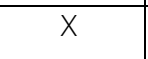 & $x$ & $x$ & $x$ & $x$ & $x$ & $x$ \\
\hline $\begin{array}{l}\text { Guerrilha } \\
\text { do } \\
\text { Araguaia }\end{array}$ & $x$ & & $X^{12}$ & $x$ & & & $x$ & $x$ \\
\hline
\end{tabular}

O Quadro 2 indica que os temas são os mesmos em praticamente todas as obras (assaltos a bancos, sequestros de diplomatas e troca por presos políticos, liderança de Carlos Marighella e Carlos Lamarca, Guerrilha do Araguaia) $)^{13}$. As exceções foram os livros de Cotrim (2005; 2016) e a edição de 2016 de Braick e Mota, que não mencionaram a Guerrilha do Araguaia, sendo que este último também não tratou de assaltos e sequestros. Na edição de 2016 do

\footnotetext{
${ }^{11}$ As trajetórias de Marighella e Lamarca ocupavam quase uma página do livro na edição de 2005. Na edição de 2006, o texto sobre tais trajetórias foi suprimido.

12 O tema é apresentado por meio de mapa e legenda, mas não é tratado no corpo do texto, tanto na edição de 2006, quanto na de 2016. O mapa baseou-se em Martins, 1978.

13 Outras ações são listadas em Campos e Miranda (2005, p. 590)) e em Campos, Pinto e Claro (2016, p. 197): treinamento de tropas, fugas de presos políticos, ataques a quartéis militares e roubos de armamentos.
} 
manual de Azevedo e Seriacopi não há referências a Carlos Marighella. Na mesma obra, há algumas imprecisões factuais. Ao tratar da repressão à Guerrilha do Araguaia, o livro diz que "os guerrilheiros foram torturados, presos e alguns foram mortos" (AZEVEDO; SERIACOPI, 2016, p. 191, grifos nossos). Na verdade, foram mais de 60 mortos (BRASIL, 2014c). Na edição anterior, esses dados estavam corretos. Em outro trecho, o manual informa que existia "cerca de uma dúzia de organizações" clandestinas de esquerda (AZEVEDO; SERIACOPI, 2005, p. 482), enquanto, segundo dados do Brasil Nunca Mais (ARQUIDIOCESES DE SÃO PAULO, 1985, p. 89), existiram quase 50. Temos aqui problemas que não foram detectados no processo de avaliação das obras, o qual tem como uma das suas metas garantir a "correção dos conceitos e informações básicas", como foi lembrado por Knauss (2009), em sua análise sobre o PNLD.

Dando continuidade à exploração dos conteúdos nos livros didáticos selecionados, vamos atentar agora para as menções a grupos armados ou clandestinos e para as referências bibliográficas relativas aos mesmos.

\section{Quadro 3 - Menções a grupos armados ou clandestinos e referências bibliográficas no capítulo}

\begin{tabular}{|c|c|c|c|c|c|c|c|c|}
\hline $\begin{array}{l}\text { Autores/as } \\
\text { e/edições }\end{array}$ & $\begin{array}{l}\text { BRAICK; } \\
\text { MOTA, } \\
2005\end{array}$ & $\begin{array}{l}\text { BRAICK; } \\
\text { MOTA, } \\
2016\end{array}$ & $\begin{array}{l}\text { CAMPOS; } \\
\text { MIRANDA, } \\
2005\end{array}$ & $\begin{array}{l}\text { CAMPOS; } \\
\text { PINTO; } \\
\text { CLARO; } \\
2016\end{array}$ & \begin{tabular}{|l|} 
COTRIM, \\
2005
\end{tabular} & $\begin{array}{l}\text { COTRIM, } \\
2016\end{array}$ & $\begin{array}{l}\text { AZEVEDO; } \\
\text { SERIACOPI, } \\
2005\end{array}$ & $\begin{array}{l}\text { AZEVEDO; } \\
\text { SERIACOPI, } \\
2016\end{array}$ \\
\hline \multicolumn{9}{|l|}{ Temas } \\
\hline $\begin{array}{l}\text { Grupos } \\
\text { clandestinos } \\
\text { mencionados }\end{array}$ & $\begin{array}{l}\text { PCB. } \\
\text { PCdoB, } \\
\text { ALN, VAR- } \\
\text { Palmares, } \\
\text { AP }\end{array}$ & $\begin{array}{l}\text { ALN, VAR- } \\
\text { Palmares. } \\
\text { VPR, MR- } \\
8\end{array}$ & $\begin{array}{l}\text { Quadro } \\
\text { geral (28 } \\
\text { org.) }\end{array}$ & $\begin{array}{l}\text { Quadro } \\
\text { geral (28 } \\
\text { org.) }\end{array}$ & & $\begin{array}{l}\text { VPR, } \\
\text { ALN }\end{array}$ & $\begin{array}{l}\text { Dissidente } \\
\text { S do PCB, } \\
\text { ALN, VPR, } \\
\text { PCdoB }\end{array}$ & $\begin{array}{l}\text { Dissidente } \\
\text { S do PCB, } \\
\text { PCdoB, } \\
\text { VPR }\end{array}$ \\
\hline $\begin{array}{l}\text { Referência } \\
\text { bibliográfica } \\
\text { sobre luta } \\
\text { armada }\end{array}$ & $\begin{array}{l}\text { Pilagallo, } \\
2002\end{array}$ & & $\begin{array}{l}\text { Reis Filho, } \\
1990\end{array}$ & \begin{tabular}{|l} 
Reis \\
Filho, \\
1990
\end{tabular} & & & $\begin{array}{l}\text { Gorender, } \\
2003 .\end{array}$ & \\
\hline
\end{tabular}

No Quadro 3 estão os grupos armados (e um partido clandestino que não optou pela via armada, O PCB) mencionados em cada um dos volumes analisados. Aí temos uma breve lista de siglas (entre duas e cinco siglas se repetem em cinco obras), um quadro geral que abrange 28 organizações (que é 
apresentado nas duas edições do mesmo livro) e, no caso da edição de 2005 de Cotrim, nenhuma menção a grupos ou siglas. Essas escolhas são representativas de uma apresentação factual do tema, na qual a menção às siglas e às lideranças de Lamarca e Marighella (como foi mostrado no Quadro 2), toma o lugar que poderia ser ocupado por uma abordagem mais analítica do processo.

No Quadro 3 consta a bibliografia indicada nos respectivos capítulos que tratam da luta armada. As obras são O Brasil em sobressalto: 80 anos de história contada pela Folha, do jornalista Oscar Pilagallo (2002), Combate nas Trevas, de Jacob Gorender (2003), cuja primeira edição é de 1987, e A revolução faltou ao encontro, de Daniel Aarão Reis Filho, na segunda edição, de 1990. Os livros de Gorender e Reis Filho foram pioneiros na historiografia que analisou a luta armada, ainda que o diálogo com as obras não seja perceptível na narrativa textual dos livros didáticos que os citam. Vemos aqui um indício do "caráter informativo enciclopédico" dos livros didáticos do Ensino Médio, reconhecido na análise de Knauss (2009, p. 307). Ao mesmo tempo, podemos estar frente a um exemplo da complexa e múltipla autoria dos livros didáticos, discutida por Cavalcanti (2016) e por Ralejo e Monteiro (2002). No mosaico composto pelo texto principal e por elementos como boxes e imagens, nem sempre as informações dialogam entre si.

Exploraremos, agora, essa falta de diálogo no que se refere à presença feminina no acontecimento mais lembrado da luta armada, o sequestro do embaixador norte-americano Charles Elbrick, episódio narrado em cinco livros didáticos analisados ${ }^{14}$. O sequestro foi a primeira iniciativa visando a libertação de militantes que estavam na prisão e contou com a participação de, pelo menos, uma mulher, Vera Sílvia Magalhães (SALEM, 1997, p. 61). O fim do sequestro do diplomata foi negociado em troca da libertação de quinze militantes que estavam na prisão, 14 homens e uma mulher, Maria Augusta Carneiro Ribeiro (TAVARES, 2012). Essas mulheres não são mencionadas em nenhum dos textos dos livros analisados. Maria Augusta, no entanto, aparece numa imagem que compõe um boxe do livro de Azevedo e Seriacopi (2005), conforme segue:

\footnotetext{
14 O sequestro do embaixador norte-americano não é mencionado em Cotrim (2005 e 2016) e na edição de 2016 de Brack e Mota.
} 


\section{Figura 1 - Ilustração do boxe "A luta armada no Brasil"}

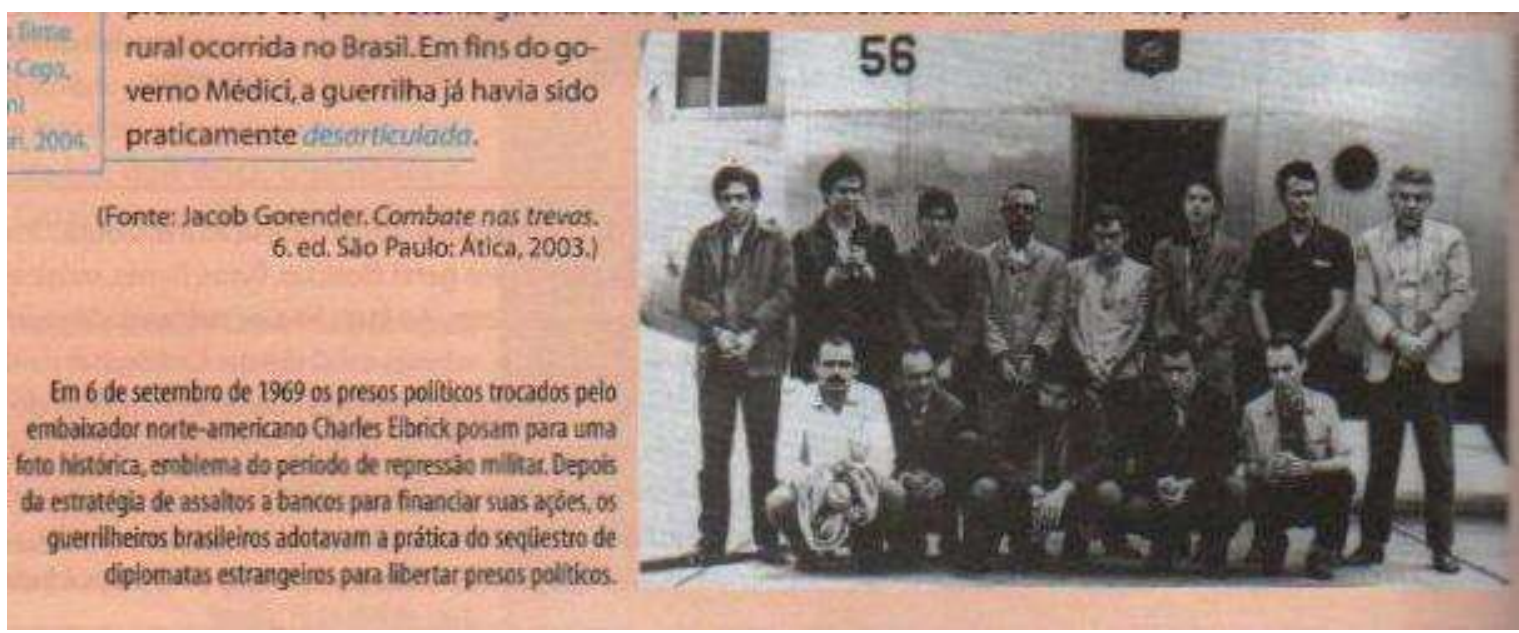

Fonte: AZEVEDO; SERIACOPI, 2005, p. $482^{15}$.

A legenda informa que em

6 de setembro de 1969 os presos políticos trocados pelo embaixador norte-americano Charles Elbrick posam para uma foto histórica, emblema do período da repressão militar. Depois da estratégia de assaltos a bancos para financiar suas ações, os guerrilheiros brasileiros adotavam a prática do sequestro de diplomatas estrangeiros para libertar presos políticos (AZEVEDO; SERIACOPI, 2005, p. 482).

$\mathrm{Na}$ imagem reproduzida pelo manual, aparecem as 13 pessoas que embarcaram num avião Hércules 56 da FAB na Base Aérea do Galeão, no Rio de Janeiro, rumo ao México. Segundo Flávio Tavares (2012, p. 116), um dos presos políticos presentes na foto, outros dois militantes foram embarcados em Recife e Belém, respectivamente. A foto, feita por militares, mostra que entre "os presos" havia uma mulher, Maria Augusta Carneiro Ribeiro, estudante de Direito, que militava na Dissidência Comunista da Guanabara (TAVARES, 2012, p. 116). Trata-se da única foto de uma mulher envolvida em grupo que optou pela luta armada que encontramos nos oito livros analisados, ainda que não apareça menção a ela nem na legenda da imagem, nem no texto do boxe do qual a fotografia faz parte.

\footnotetext{
${ }^{15}$ A segunda edição do livro suprimiu esta foto.
} 
Em contraposição a isso, outro manual, ao tratar do sequestro do embaixador e do mesmo grupo de militantes, nomeia alguns dos presos libertados. Em um boxe da edição de 2005 de Braick e Mota consta que "o embaixador foi solto em troca da libertação de quinze prisioneiros políticos, embarcados rumo ao México. Entre eles, os principais líderes estudantis: Palmeira, Travassos e Zé Dirceu" (BRAICK; MOTA, 2005, p. 161). Ou seja, nos trechos analisados, mulheres não são retratadas nem de forma genérica. Homens são contemplados em expressões como "presos políticos" e parte deles têm os nomes mencionados.

Num balanço do que foi encontrado nos livros analisados sobre o tema "mulheres na luta armada", temos: 1) a menção aos combatentes da luta armada como sendo "homens e mulheres" (AZEVEDO; SERIACOPI, 2016, p. 190); 2) os nomes de Maria Lúcia Petit da Silva, militante do PCdoB, morta na Guerrilha do Araguaia, e de Esmeraldina Carvalho Cunha, cuja filha não nomeada participou do MR-8 (AZEVEDO; SERIACOPI, 2016, p. 192), ainda que elas tenham sido apresentadas como parte do grupo de mortos e desaparecidos; e, 3) a imagem (não nominada) de Maria Augusta Carneiro Ribeiro na foto do grupo libertado em troca do embaixador norte-americano (AZEVEDO; SERIACOPI, 2005, p. 882). Não encontramos nenhuma outra referência direta ao protagonismo de mulheres num capítulo da história da ditadura que os oito livros analisados escolheram retratar.

Uma das possíveis explicações para esse quadro está na centralidade dada à história política e econômica na narrativa textual e imagética dos livros analisados. Trata-se de uma história eminentemente masculina, política e institucional, povoada por nomes e fotos de homens, siglas de partidos, órgãos governamentais, planos econômicos. É uma história de homens adultos e velhos, com algumas menções a homens jovens e a quase invisibilidade das mulheres. Encontramos um panorama próximo daquele descrito na resenha de 2008 sobre o livro de Cotrim (2005): "grande destaque à atuação de líderes políticos, muito em função da opção por uma narrativa política e factual (BRASIL, 2008, p. 78-9).

Isso se aproxima também da constatação de Helenice Rocha ao examinar narrativas sobre a ditadura nos livros do PNLD 2011. A autora encontrou uma 
sucessão de generais, suas realizações e de atos institucionais (ROCHA, 2017, p. 258). Ela percebeu que os livros "mencionam oposição, mas não fica claro quem faz parte da oposição" e que "poucas coleções mencionam explicitamente a participação da sociedade civil durante a ditadura, atribuindo a determinados representantes da elite uma aliança com os militares" (ROCHA, 2017, p. 255 e 257). O silêncio que a autora encontrou em relação à sociedade civil e ao consentimento social às ações de repressão nós encontramos em relação à presença de mulheres na luta armada, com pequenas exceções.

\section{Uma historiografia em construção e os indícios de mulheres como protagonistas}

Em texto publicado em 2007, Cristiane Bereta da Silva buscou indícios sobre as mulheres e as relações de gênero nos livros didáticos de História nas duas décadas que antecederam a escrita de seu artigo. Nesse esforço, ela constatou, entre outras coisas, que

as alterações, no campo da renovação e incorporação historiográfica, passaram a ser realizadas a partir de inúmeros links, boxes, textos dentro de outros textos, bem como com uma pluralidade de imagens - que hoje caracterizam os livros didáticos de modo especial. Esses recursos, de certa forma, abriram apenas "parênteses" para que questões que envolvam aspectos da vida cotidiana, privada e, assim, por associação histórica, da história das mulheres e das relações de gênero, fossem abordadas. (SILVA, 2007, p. 228, grifos nossos)

É interessante a proximidade entre essa constatação e aquilo que encontramos nos livros analisados para a escrita deste texto. Ao acompanhar epígrafes e boxes espalhados pelos capítulos que tratam da história da ditadura - e não apenas das partes do texto principal que se referem à luta armada acabamos encontrando depoimentos e nomes de mulheres que participaram dessa forma de combate à ditadura. Assim como no estudo de Rocha (2017), vemos no trabalho de Bereta da Silva (2007) um diálogo entre os desenvolvimentos da historiografia e a produção dos livros didáticos, preocupação que também orienta o presente artigo. 
As informações indiretas sobre a presença de mulheres em grupos que optaram pela luta armada que encontramos nos livros didáticos selecionados foram retiradas majoritariamente do Brasil Nunca Mais (ARQUIDIOCESE DE SÃO PAULO, 1985), de cujo texto foram selecionados testemunhos de mulheres torturadas ou relatos feitos por mulheres sobre a tortura aplicada a outras pessoas. Além do Brasil Nunca Mais, depoimentos foram buscados no site do grupo Tortura Nunca Mais (BRAICK; MOTA, 2005, p. 167) e foram feitas menções ao Comitê Catarinense Pró-Memória de Mortos e Desaparecidos Políticos (BRAICK; MOTA, 2005, p. 167), à Comissão Especial sobre Mortos e Desaparecidos Políticos (AZEVEDO; SERIACOPI, 2005, p. 483; 2016, p. 192) e à Comissão Nacional da Verdade (AZEVEDO; SERIACOPI, 2016. p. 192). Trata-se de coletivos da sociedade civil e de órgãos do Estado envolvidos na luta por memória, verdade e justiça em relação aos crimes da ditadura.

Ao serem mencionados esses coletivos, os textos dos livros analisados registraram os nomes das seguintes mulheres: Amparo Araújo, Criméia de Almeida, Derlei Catarina de Luca, Esmeraldinha de Bastos Cunha, Ilda Brande Siegel e Iná de Souza Medeiros, Maria Lúcia Petit da Silva e Marlene de Souza Soccas ${ }^{16}$. Pelo menos quatro delas - Maria do Amparo Almeida Araújo, Criméia Alice Schmidt de Almeida, Maria Lúcia Petit da Silva e Marlene de Souza Soccas - participaram de organizações envolvidas na luta armada: a primeira na ALN, a segunda e a terceira no Partido Comunista do Brasil (PCdoB) e a última na VPR ${ }^{17}$. Por acaso ou não, e conforme consta no Quadro 3, a ALN e a VPR foram as organizações que apareceram em quase todos os livros analisados. No caso do PCdoB, ele foi o protagonista da Guerrilha do Araguaia, tema que foi apresentado em seis dos oito manuais examinados ${ }^{18}$.

\footnotetext{
16 Sobre Amparo Araújo e Derlei Catarina de Luca (BRAICK; MOTA, 2005, p. 167); sobre Ilda Brande Siegel e Iná de Souza Medeiros (BRAICK; MOTA, 2005, p. 162); sobre Criméia de Almeida (BRAICK; MOTA, 2016, p. 168); sobre Marlene de Souza Soccas (BRAICK; MOTA, 2016, p. 174); sobre Esmeraldinha de Bastos Cunha e Maria Lúcia Petit da Silva (AZEVEDO, SERIACOPI, 2016. p. 192).

17 Sobre Maria do Amparo Almeida Araújo, ver Pernambuco (2013); para Criméia Alice Schmidt de Almeida, conferir Nietto (2019); sobre Maria Lúcia Petit da Silva, ver Sousa (2013); e para Marlene de Souza Soccas, ver Abreu e Lima (2008).

18 Em relação às outras mulheres mencionadas, Derlei Catarina de Luca foi uma liderança do movimento estudantil catarinense e militante da Ação Popular, organização não envolvida em ações armadas. Sobre essa militante, ver DE LUCA (2002) e REIS (2020). Ilda Brande Siegel e Iná de Souza Medeiros tiveram seus nomes mencionados a partir de depoimentos prestados à Justiça Militar, compilados no Brasil Nunca Mais (ARQUIDIOCESE DE SÃO PAULO, 1985). Sobre Esmeraldina de Bastos Cunha, comentamos acima.
} 
No entanto, essas mulheres não são apresentadas como ex-combatentes da luta armada. Elas aparecem na condição de militantes da memória, pessoas que têm uma autoridade de fala decorrente da experiência vivida, de uma "experiência pessoal de sofrimento corporal" (JELIN, 2002, p. 61) e que se dedicam a empreendimentos de memória como militância política. Ou seja, ainda que os livros aqui estudados sejam praticamente omissos no tema do protagonismo de mulheres na luta armada, um olhar cuidadoso pode encontrar nas mesmas obras indícios da presença dessas mulheres.

Na mesma direção - a de atentar para elementos que não fazem parte do texto principal, informações que aparecem na forma de "parênteses", como disse Bereta da Silva (2007) - queremos retomar as referências bibliográficas apresentadas pelos manuais nos trechos que tratam da luta armada. Vimos no Quadro 2 que as referências se resumem a um texto jornalístico (PILAGALLO, 2002) e a dois livros de historiadores (GORENDER, 2003 e REIS FILHO, 1990). A equipe responsável pela autoria dos livros didáticos analisados, no entanto, não dialogou nem com as abordagens propostas pelos dois historiadores, nem com produções mais recentes, que enfocam de forma mais circunscrita as ações dos grupos envolvidos na luta armada, a vigilância e a repressão a eles ou com pesquisas que tratam da participação de mulheres em tais processos.

Essa constatação se aproxima daquela feita por Sônia Regina Miranda e Tânia Regina de Luca (2004) em artigo sobre o livro didático de História a partir do PNLD. Considerando a avaliação dos livros de História divulgada no início de 2004 e da qual as autoras participaram, Miranda e De Luca concluíram que "ainda existe um enorme abismo entre a renovação historiográfica advinda da pesquisa historiográfica e o saber histórico veiculado por meio do livro didático” (MIRANDA, LUCA, 2004, p. 141). Aqui também encontramos a incorporação de "acréscimos pontuais" e "o caráter de justaposição" (KNAUSS, 2009, p. 307). Na mesma direção, Helenice Rocha (2017, p. 265), ao compilar as bibliografias finais em livros didáticos que tratam do período da ditadura, dirigidas ao professor e dirigidas a estudantes, encontrou obras panorâmicas, como os livros de Thomas Skidmore, Elio Gaspari e Boris Fausto. 
Para refletir sobre uma das obras utilizadas como referência para o tratamento do tema da luta armada e da presença de mulheres na mesma, vamos nos deter no livro Combate nas trevas, de Jacob Gorender (1987). Misto de registro de memória e de cuidadosa pesquisa documental, o livro de Gorender (1987) descreve os grupos de esquerda e seus (e suas) participantes. Ainda que o autor sempre empregue o masculino genérico ao usar expressões como "os guerrilheiros", "os presos políticos" (como na maioria dos livros didáticos selecionados para esse artigo), e ainda que ele não tenha se proposto a analisar a participação de mulheres na luta armada ou as relações de gênero nesse contexto, Gorender apresenta os nomes e a atuação de diversas mulheres, como podemos ver na compilação que segue ${ }^{19}$.

Uma das mulheres mencionadas é Sônia Lafoz, que fez parte da Dissidência Estudantil do PCB e depois integrou a VPR. Outra é Maria do Carmo Brito, conhecida como Lia, eleita para a direção do mesmo grupo, junto com Jamil Rodrigues, codinome de Ladislau Dowbor, e com Lamarca, o militante cujo nome apareceu em todos os livros analisados ${ }^{20}$. Lucia Murat de Vasconcelos, militante que participou das tratativas de aproximação entre o MR-8 e a VAR também é lembrada por Gorender. Inês Etienne Romeu, a Olga, é apresentada como tendo feito parte da direção da VPR, numa recomposição do grupo, ao lado de Lamarca e Herbert Daniel. As militantes do Partido Comunista Brasileiro Revolucionário (PCBR), Nancy Mangabeira Unger e Vera Maria Pereira, são mencionadas por terem sido presas no contexto de um plano do partido para sequestrar o cônsul do Japão. O nome de Zenaide Machado de Oliveira é registrado pelo autor, ao tratar de "quedas" e prisões de membros da VPR. Os casos de duas participantes da ALN, Ana Maria Nacinovic Corrêa e Sônia Maria Lopes Moraes, vitimadas por agentes do DOI/CODI, em 1972 e 1973, respectivamente, também são lembrados. A segunda é apresentada como excompanheira de Stuart Angel Jones. lara lavelberg, por sua vez, aparece

\footnotetext{
19 Lista das páginas de Gorender (1987) nas quais estão as menções a cada uma das mulheres: Sônia Lafoz, p. 132; Maria do Carmo Brito, p. 137; Lucia Murat de Vasconcelos, p.185); Inês Etienne Romeu, p. 191; Nancy Mangabeira Unger e Vera Maria Pereira, p. 193; Zenaide Machado de Oliveira; p. 198; Ana Maria Nacinovic Corrêa e Sônia Maria Lopes Moraes, p. 204; p, 199; Dinalva Teixeira, p. 210; Aurora Maria Nascimento Furtado, p. 205.

${ }^{20}$ Sobre Maria do Carmo Brito, ver VIANNA, 2003.
} 
acompanhando Carlos Lamarca na viagem para a Bahia, em junho de 1971, com a intenção de abertura de um núcleo de guerrilha rural ${ }^{21}$. No caso da Guerrilha do Araguaia, Gorender informa que Dinalva Teixeira, a Dina, teria “tombado" em outubro de 1973. O autor ainda se refere a Aurora Maria Nascimento Furtado, "a destemida guerrilheira da linha de frente da ALN".

Não tivemos aqui a intenção de listar todos os nomes de mulheres registrados por Gorender na primeira edição de sua obra, mas acreditamos que os acima apresentados já são indicativos da presença de mulheres nesse capítulo da história da luta contra a ditadura. Várias das mencionadas perderam a vida por conta de sua militância e a menção aos seus nomes contribui para valorizar sua experiência e honrar sua memória, como acontece em muitos monumentos que homenageiam vítimas de ditadura no Cone Sul da América Latina. É uma das contribuições que este texto pretende dar no sentido de que as ausências constatadas nos livros didáticos podem/devem instigar a busca de outros recursos que permitam mostrar a existência dessas mulheres e de seus engajamentos. É, ainda, um esforço inspirado nas discussões sobre mulheres e gênero, acima mencionados e que tem como um de seus propósitos iniciais o de dar visibilidade à presença das mulheres na história.

Nessa mesma direção, se coligirmos outras fontes, podemos ampliar a lista de mulheres envolvidas na luta armada e podemos, ainda, conhecer múltiplas dimensões da experiência vivida. Por conta disso, consideramos pertinente apresentar mais algumas mulheres e os temas que têm sido enfocados em pesquisas sobre a presença de mulheres na luta contra a ditadura e nos grupos armados.

De acordo com Olívia Joffily, Vera Sílvia Magalhães fez parte do Comitê Central da Dissidência da Guanabara, depois MR-8; Dulce Maia foi uma das fundadoras da VPR e componente da sua direção; Guiomar Lopes, participante da direção da ALN, “foi responsável pelo Grupo Tático Armado”; e Carmela Pezzuti foi militante do Grupo Colina, Comandos de Libertação Nacional (JOFFILY, 2016, p. $113,173,189)^{22}$. A primeira militante mencionada - Vera Sílvia - participou das

\footnotetext{
${ }^{21}$ Para a trajetória de lara lavelberg, ver ainda Patarra (1992); Frederico (2003) e Pamplona (2009). 22 Sobre Carmela Pezzuti, ver Paiva (1996).
} 
ações que possibilitaram o sequestro do embaixador norte-americano, como já foi mencionado (SALEM, 1997, p. 61). Ainda sobre o tema dos sequestros de diplomatas, no livro Os Carbonários: memória da guerrilha perdida, o ex-militante Alfredo Syrkis (1980, p. 247-262), se refere a uma mulher de nome Helga, casada com um dos sequestradores, de nome Ivan, como tendo estado presente no cativeiro do diplomata suíço e participado nas decisões do grupo. Antonieta Campos da Paz fez parte da direção da ALN (RIBEIRO, 2011, p. 94). Ignez Maria Serpa Ramminger, também conhecida como "Martinha", participou do comando da Vanguarda Armada Revolucionária (VAR-Palmares) no Rio Grande do Sul (RAMMINGER, 2009, p. 140-141), tendo estado envolvida em ações como o assalto à agência do Banco do Brasil na cidade de Viamão, na região metropolitana de Porto Alegre (RAMMINGER, 2010, p. 139-140).

Tendo chamado a atenção das leitoras e dos leitores para esse conjunto de mulheres, apresentaremos agora alguns trabalhos acadêmicos mais recentes que permitem vislumbrar diferentes nuances da militância de mulheres em grupos da esquerda armada. Em sua tese de doutorado, Maria Cláudia Badan Ribeiro (2011), tratou da participação de mulheres em redes de solidariedade e de apoio à ALN e analisou um conjunto de atividades de colaboração que permitia a atuação do núcleo militar. A autora procurou demonstrar "a maneira através da qual a ALN também funcionou como uma escola para essas mulheres" (RIBEIRO, 2011, p. 383). Ao explorar atividades de apoio - "lugares para as reuniões, alimentos, remédios, abrigo às pessoas procuradas, esconderijo de armas, material explosivo ou ajudar a dar fuga aos marcados para morrer", entre outras - a autora entendeu que "não eram realizadas em função de seu sexo. Ser homem ou mulher não era um fator de diferenciação ou impedimento" (RIBEIRO, 2011, p. 384).

Outras pesquisas tratam dos constrangimentos de gênero na luta armada. Em artigo publicado em 2010, Cristina Scheibe Wolff, analisa o "gênero da esquerda em tempos de ditadura", comparando as experiências dos países do Cone Sul nas décadas de 1960 e 1970, nos quais "grupos ligados aos partidos de esquerda (...) se propunham a transformar a sociedade pela força do fuzil" (WOLFF, 2010, p. 138). Levando em conta as particularidades históricas de cada 
país, a autora explora variáveis como a constituição de uma nova moral sexual entre a militância, o acesso das mulheres às organizações por meio do movimento estudantil, as dificuldades das mulheres em avançarem nos postos de comando das organizações. Segundo Wolff (2010, p. 150), paralelamente a um discurso que destacava "as qualidades viris dos guerrilheiros, as organizações tiveram que lidar com militantes homens e mulheres. Teriam que assumir estratégias diversas para a incorporação de mulheres e aceitá-las como iguais. Isso nem sempre foi fácil". As dificuldades enfrentadas pelas mulheres para avançarem em cargos de comando também são analisadas no texto de Isabel Cristina Hentz e Ana Maria Veiga (2011), e que trata das relações entre feminismo e esquerda nas ditaduras do Cone Sul. As autoras lembram que era "muito difícil que mulheres atingissem cargos de comando dentro de uma organização de esquerda e quando atingiam a cobrança sobre elas era maior do que sobre os homens" (HENTZ; VEIGA, 2011, p. 153).

Finalmente, destacamos que a presença feminina na luta armada também é tratada na tese de doutorado de Tauana Olívia Gomes Silva (2019), a qual analisa o protagonismo das mulheres negras na luta conta a ditadura, dando destaque à trajetória de nove mulheres. Duas delas tiveram participação na Guerrilha do Araguaia - Helenira Resende de Souza Nazareth e Lúcia Maria de Souza. Das conclusões do trabalho, destacamos a que segue:

as mulheres, especialmente as negras, no contexto de suas atuações opostas à ditadura, tiveram que superar diferentes obstáculos de ordem material, moral e psicológica intrínsecos à sua condição subalterna na sociedade. No entanto, penso também que foi no âmbito dos grupos resistentes de esquerda, perante diferentes discursos de negação de suas capacidades intelectuais e militantes, bem como perante a "divisão sexual" do trabalho revolucionário, o qual rejeitava suas especificidades, que as informantes inicialmente tornaram-se sujeitos políticos da luta antirracista e feminista. (SILVA, 2019, p. 453)

Reiteramos que nossa intenção ao apresentar essas pesquisas foi a de demonstrar que existem estudos sobre mulheres na luta armada, os quais foram sendo desenvolvidos ao longo do tempo em diálogo com movimentos sociais, políticas públicas e debates teóricos e historiográficos. Desenvolveram-se concomitantemente às políticas públicas para o livro didático e àquelas voltadas 
à herança da ditadura, no seio dos quais se destacam os trabalhos da Comissão Nacional da Verdade (BRASIL, 2014a). Assim, os debates políticos e acadêmicos travados no meio tempo entre os PNLEM 2008 e 2018, contribuíram para repensar a história da ditadura e da luta armada, a partir do reconhecimento das violações de direitos humanos de mulheres, camponeses/as, indígenas, pessoas LGBTQIA+, trabalhadores urbanos etc. São novos desafios para a historiografia e para o ensino escolar de história.

\section{Considerações finais}

No primeiro tópico deste texto, analisamos as resenhas publicadas em 2008 e 2018 nos guias do PNLEM sobre os oitos livros didáticos selecionados. Constatamos que as menções a conceitos, abordagens e objetos que poderiam se aproximar de nosso tema de estudo (mulheres, gênero, história das mulheres, relações de gênero etc.) apareceram de forma imprecisa. A seguir, na análise da narrativa textual, imagética e gráfica dos livros didáticos, nas partes que em foi tratado o contexto da ditadura, da luta armada e do auge da repressão, buscamos menções sobre mulheres, encontrando poucos registros, alguns diretos, como protagonistas, e outros indiretos, como testemunhas ou vítimas da repressão.

No último tópico do artigo, ao contrapor as poucas referências diretas a mulheres na luta armada encontradas com a lista de mulheres mencionadas por Gorender (1987) e aos nomes de outras mulheres cuja trajetória foi objeto de estudos posteriores, quisemos demonstrar a disponibilidade de indícios de sua presença nesse capítulo da história do Brasil. Não apenas indícios, mas um conjunto robusto de subsídios que pode ser utilizado por docentes para conhecer mais de perto a experiência dessas mulheres e, com isso, ter condições de utilizar os livros didáticos de forma mais crítica e criativa. A atenção para uma determinada imagem ou para o nome de uma mulher nos "parênteses" do texto principal - como os representados por boxes e imagens - pode ser o ponto de partida para a exploração de um tema que não mereceu a devida atenção de autores/as e editoras, e que apresentou poucas mudanças entre os livros do PNLEM de 2008 e de 2018 aqui analisados. 
Considerando a existência de materiais como pesquisas acadêmicas, livros de memória, reportagens jornalísticas, filmes, documentários, documentos oficiais do Estado brasileiro tratando da participação feminina na luta armada contra a ditadura, concluímos ser no mínimo problemático o "esquecimento" do protagonismo de mulheres nos livros selecionados. Ao mesmo tempo, lembramos que o conjunto de esforços realizados nesse meio tempo por setores da sociedade civil e do Estado no equacionamento das heranças da ditadura, cujo auge foi a publicação do Relatório Final da Comissão Nacional da Verdade, e a intensa renovação historiográfica que marcou o mesmo período, criaram a expectativa e as condições para que a história da ditadura nos livros didáticos pudesse ser transformada, o que parece ainda não ter acontecido.

O tratamento panorâmico e rápido de questões complexas é um desafio cotidianamente enfrentado por qualquer um/uma de nós ao escrever e ao ensinar história e muito mais na produção dos livros didáticos. Fica, no entanto, o desejo de que as escolhas narrativas, factuais, imagéticas, gráficas, feitas na elaboração dos manuais permitam que os/as estudantes se aproximem da experiência vivida, das expectativas, medos e frustrações de mulheres e de homens que consideraram possível enfrentar o regime e a repressão pelas armas; que contribuam para que as jovens e os jovens se questionem sobre as particularidades da experiência de repressão política vivida no final dos anos 1960 e no início dos 1970 e esteja alerta frente aos discursos que hoje clamam pela volta dos militares ao poder e apresentam a tortura de forma positiva; que nossos/as estudantes tenham condições de construir um entendimento, mínimo que seja, sobre os confrontos que estiveram na origem de boa parte das prisões, torturas, mortes e desaparecimentos legados a nós pela ditadura; que possam, enfim, conhecer experiências de mulheres que, ao pegar em armas, se apropriaram do espaço da política e questionaram as hierarquias de gênero então vigentes, as quais em grande medida ainda operam nos dias de hoje e continuam afetando nossa existência. 


\section{Referências}

ARAÚJO, Maria Paula Nascimento. Memória e debate sobre a luta armada no Braisl e na Argentina. In: QUADRAT, Samantha Viz; ROLLEMBERG, Denise (Orgs.). História e memória das ditaduras do século XX. Rio de Janeiro: FGV Editora, 2015, p. 245-263.

ARQUIDIOCESE DE SÃO PAULO. Brasil: Nunca Mais: um relato para a história. Petrópolis: Vozes, 1985.

AZEVEDO, Reinaldo; SERIACOPI, Gislaine. História passado e presente. São Paulo: Ática, 1ae ed., 2016, vol. 3.

AZEVEDO, Reinaldo; SERIACOPI, Gislaine. História. São Paulo: Ática, 1a ed., 2005, vol. único.

BAUER, Caroline. Quanta verdade o Brasil suportará? Uma análise das políticas de memória e de reparação implementadas o Brasil em relação à ditadura civilmilitar. In: Dimensões. Revista de História da UFES, v. 32, p. 148-169, 2014.

BRAGA, Gilberto. Minissérie “Anos Rebeldes”. Rio de Janeiro: Rede Globo, 1992.

BRAICK, Patrícia Ramos; MOTA, Myriam Becho. História das cavernas ao terceiro milênio. São Paulo: Moderna, 1a ed., 2005, vol. 3.

BRAICK, Patrícia Ramos; MOTA, Myriam Becho. História das cavernas ao terceiro milênio. São Paulo: Moderna, 4ae ed., 2016, vol. 3.

BRASIL. Ministério da Educação/Secretária da Educação Básica. Catálogo do Programa Nacional do Livro Didático para o Ensino Médio, PNLEM/2008. Brasília, 2008.

BRASIL. Ministério da Educação/Secretária da Educação Básica. Guia Digital PNLEM/2018. Disponível em: https://www.fnde.gov.br/pnld-2018/ Acesso: 19 março 2021.

BRASIL. Mortos e desaparecidos políticos. Relatório Final da Comissão Nacional da Verdade, Brasília, 2014c, vol. 3.

BRASIL. Relatório Final da Comissão Nacional da Verdade, Brasília, 2014a, 3 vols.

BRASIL. Violência sexual, violência de gênero e violência contra crianças e adolescentes. Relatório Final da Comissão Nacional da Verdade, Brasília, 2014b, vol. 1, p. 399 a 435.

BRIGGMANN, Luísa Dornelles. Mulheres que foram à luta contra a ditadura nas páginas do jornal Correio do Povo (1968 - 1975). Florianópolis: UFSC, 2019. Dissertação de mestrado em História. 
CAIMI, Flávia Eloisa. O livro didático de história e suas imperfeições.

Repercussões do PNLD após 20 anos. In: ROCHA, Helenice; REZNIK, Luis; MAGALHÃES, Marcelo de Souza (orgs.). Livros Didáticos de História: entre políticas e narrativas. Rio de Janeiro: FGV Editora, 2017, p. 33-54.

CAMPOS, Flávio de; PINTO, Júlio Pimentel de; CLARO, Regina. Oficina de História, São Paulo: Leya, 2016, vol. 3

CAMPOS, Flávio; MIRANDA, Renan Garcia. A escrita da história. São Paulo: Escala Educacional, 2005, vol. único.

CARBONI, Maria Cecília Conte. Maria Quitéria: o Movimento Feminino pela Anistia e sua imprensa (1975-1979). 2008. 98 f. Dissertação (Mestrado em História) - Pontifícia Universidade Católica de São Paulo, São Paulo, 2008.

CARVALHO, Luiz Maklouf. Mulheres que foram à luta armada. São Paulo: Globo, 1998.

CAVALCANTI, Erinaldo. Livro didático: produção, possibilidades e desafios para o ensino de História. Revista História Hoje, v. 5, no 9, p. 262-284, 2016.

CHOPPIN, Alain. O historiador e o livro escolar. História da Educação, n. 11, p. 5 24, abril de 2002.

COLLING, Ana Maria. A construção do sujeito político mulher "subversiva". In.: Contexto e Educação, Ijui, v. 9, no 35, p. 16-23, jul/set. 1994.

COLLING, Ana Maria. A resistência da mulher à ditadura militar no Brasil. Rio de Janeiro: Record: Rosa dos Ventos, 1997.

COLLING, Ana Maria. As mulheres e a ditadura militar no Brasil. In.: História em Revista. v.10, UFPEL, 2004.

COSTA, Albertina de Oliveira; MORAES, Maria Teresa Porciuncula; MARZOLA, Norma; LIMA, Valentina da Rocca. Memórias das mulheres do exílio. Rio de Janeiro: Paz e Terra, 1980, 2 vols.

COTRIM, Gilberto. História Global. São Paulo: Saraiva, 2a ed., 2016, vol. 3.

COTRIM, Gilberto. História Global: Brasil e Geral. São Paulo: Saraiva, 1a ed., 2005, vol. único.

DA-RIN, Sílvio (Dir.). Hércules 56 (Documentário), 2006.

DE LUCA, Derlei Catarina. No corpo e na alma. Criciúma: Do autor, 2002.

DUARTE, Ana Rita Fontelles. Memórias em disputa e jogos de gênero: o Movimento Feminino pela Anistia no Ceará (1976-1979). 2009. 232 f. Tese 
(Doutorado em História) - Universidade Federal de Santa Catarina, Florianópolis, 2009.

FAGUNDES, Pedro Ernesto Anistia: das mobilizações das mulheres na ditadura militar às recentes disputas sobre o passado. Vitória: Editora Milfontes, 2019.

FERREIRA, Elizabeth F. Xavier. Mulheres, militância e memória. Rio de Janeiro: Fundação Getúlio Vargas, 1996.

FREDERICO, Flávio (Dir.). Em busca de lara (Documentário), 2003.

GORENDER, J. Combate nas Trevas: a esquerda brasileira: das ilusões perdidas à luta armada. São Paulo: Ática, 1987.

HENTZ, Isabel Cristina e VEIGA, Ana Maria. Entre o feminismo e a esquerda: contradições e embates da dupla militância. In: PEDRO, Joana Maria; WOLFF, Cristina Scheibe; VEIGA, Ana Maria (Orgs.). Resistências, gênero e feminismos contra as ditaduras do Cone Sul. Florianópolis: Editora Mulheres, 2011, p. 145163.

INSUELA, Júlia Bianchi Reis. Visões das mulheres militantes na luta armada: repressão, imprensa e (auto)biografias (Brasil, 1968-1971). Niterói: Universidade Federal Fluminense, 2011. Dissertação de Mestrado em História.

JELIN, Elizabeth. Los trabajos de la memoria. Madri: Siglo XXI, 2002.

JOFILLY, Olívia R. Esperança Equilibrista: resistência feminina à ditadura militar no Brasil. Florianópolis: Insular, 2016.

KNAUSS, Paulo. Por onde anda a história na atualidade da escola: ensino médio, livros didáticos e ensino de história. In: ROCHA, Helenice; MAGALHÃES, Marcelo; CONTIJO, Rebeca (orgs.). A escrita da história escolar: memória e historiografia. Rio de Janeiro: Editora FGV, 2009. p. 293-308.

MACHADO, Vanderlei. Paternidade, maternidade e ditadura: a atuação de pais e mães de presos, mortos e desaparecidos políticos no Brasil. História Unisinos, v. 17, p. 179-188, 2013.

MACHADO, Vanderlei; RODEGHERO. Carla Simone. Os Livros didáticos e a História da participação das mulheres no Movimento Estudantil. Fronteiras: Revista Catarinense de História, v. N. 29, p. p. 28-49, 2017.

MARTINS, I. de. A Guerrilha do Araguaia. In: História Imediata. São Paulo: Alfaômega, 1978, vol. 1.

MATOS, Maria Izilda Santos. História das Mulheres e das Relações de Gênero: Campo Historiográfico, Trajetórias e Perspectivas. In: Mandrágora, v. 19, p. 5-15, 2013. 
MIRANDA, Sônia Regina; LUCA, Tânia Regina de. O livro didático de história hoje: um panorama a partir do PNLD. In: Revista Brasileira de História. Vol. 14, n. 48, p. 123-143, dez. 2004.

MURAT, Lúcia (Dir.). Que Bom Te Ver Viva (Documentário), 1989.

NIETTO, Rose Marie. Memórias, identidades e o processo de formação política de Marlene Soccas : uma militante de esquerda em tempos de Ditadura Civil Militar no Brasil (1960 -1970). Criciúma/SC: Unesc, 2019. Dissertação de mestrado em educação. Disponível em:

http://repositorio.unesc.net/handle/1/7536. Consulta em 13 de março de 2021.

PAIVA, Maurício. Companheira Carmela. A história da lua de Carmela Pezzuti e seus dois filhos na resistência ao regime militar e no exílio. Rio de Janeiro: MAUAD, 1996.

PAMPLONA, Mariana. Clandestina, a vida de lara lavelberg em dois roteiros. 2009. 122 p. Dissertação (mestrado) - Universidade Estadual de Campinas, Instituto de Artes, Campinas, SP.

PATARRA, Judith. lara: reportagem biográfica. Rio de Janeiro: Rosa dos Tempos, 1992.

PAULA, Adriana das Graças de. Pensar a democracia: o movimento feminino pela anistia e as Mães da Praça de Maio (1977-1985). 2014. 155 f. Dissertação (Mestrado em História) - Universidade de São Paulo, São Paulo, 2014.

PEDRO, Joana Maria; VEIGA, Ana Maria. Gênero. In: COLLING, Ana Maria; TEDESCHI, Losandro (Orgs.). Dicionário crítico de gênero. Dourados, MS: Ed. UFGC, 2015, p. 304-308.

PEDRO, Joana Maria; WOLFF, Cristina Scheibe; VEIGA, Ana Maria. (Org.). Resistências, Gênero e Feminismos contra as Ditaduras no Cone Sul. 1ed. Florianópolis: Mulheres, 2011.

PERNAMBUCO, Estado de. Secretaria da Casa Civil. Comissão Estadual da Memória e Verdade D. Helder Câmara. Depoentes Ivan Seixas e Amparo Araújo. 04/04/2013. Disponível em https://www.comissaodaverdade.pe.gov.br/index.php/28-11-04-2013-p-ivanseixas-e-amparo-araujo-pdf-3 Consulta em 14/03/2021.

PILAGALLO, Oscar. O Brasil em sobressalto: 80 anos de história contada pela Folha. São Paulo: Folha de São Paulo, 2002.

RALEJO, Adriana; MONTEIRO, Ana Maria. Livros didáticos: autoria em questão. In: Revista Escritas do Tempo - v. 2, n. 5, Jul.-Out./2020, p. 117-13. 
RAMMINGER, Ignez M. S. Na guerra com batom. In: PADRÓS, Enrique S.; BARBOSA, Vânia M.; LOPEZ, Vanessa Al.; FERNANDES, Ananda S. (org). A Ditadura de Segurança Nacional no Rio Grande do Sul (1964 - 1985): história e memória. POA: Corag, 2010 - vol. 2.

REIS FILHO, Daniel A. A Revolução Faltou ao Encontro. Os Comunistas no Brasil. São Paulo: Brasiliense, 1990.

REIS, Débora Ataíde. Memória(s) Militante(s): narrativas autobiográficas e imagens da resistência em Derlei Catarina de Luca (1966-1973). Salvador: UFBA, 2020. Dissertação de mestrado em História.

REZENDE, Sérgio (Dir.). Zuzu Angel, 2006.

RIBEIRO, Maria Cláudia Badan. Experiência de luta na emancipação feminina: mulheres na ALN. São Paulo: USP, 2011, Tese de doutorado em História.

RIDENTI, Marcelo. As mulheres na política brasileira: os anos de chumbo. Tempo Social, Rev. Sociol. USP, S. Paulo, 2 (2), 113-128, 2o sem. 1990.

ROCHA, Helenice. A ditadura militar nas narrativas didáticas. In: ROCHA, Helenice; REZNIK, Luis; MAGALHÃES, Marcelo de Souza (orgs.). Livros Didáticos de História: entre políticas e narrativas. Rio de Janeiro: FGV Editora, 2017, p. 245-468.

RODEGHERO, Carla S.; GUAZZELLI, Dante G.; DIENSTMANN, Gabriel. NÃO CALO, GRITO: Memória visual da ditadura civil-militar no Rio Grande do Sul. Porto Alegre: Tomo Editorial, 2013.

RODEGHERO, Carla Simone; DIENSTMANN, Gabriel; TRINDADE, Tatiana. Anistia ampla, geral e irrestrita: história de uma luta inconclusa. Santa Cruz do Sul: Edunisc, 2011.

RODEGHERO, Carla Simone; MACHADO, Vanderlei. A História recente nos livros didáticos de História: a ditadura militar e a questão da anistia no Brasil. Cadernos do Aplicação (UFRGS), v. 23, p. 165-198, 2010.

RODEGHERO, Carla Simone; MACHADO, Vanderlei. Mulheres em movimento: militância estudantil e luta contra a ditadura. In: História Oral, v. 20, n. 2, p. 3357, jul./dez. 2017.

ROVAI, Marta Gouveia de Oliveira. O direito à memória: a história oral de mulheres que lutaram contra a ditadura militar (1964 - 84). Revista Tempo e Argumento, Florianópolis, v. 5, n.10, jul./dez. 2013. p. 108 - 132.

SALEM, Helena. Ex-militante inspira personagens femininas: entrevista com Vera Sílvia Magalhães. In: REIS FILHO, Daniel Aarão (Org.). Versões e ficções: o sequestro da história. São Paulo: Editora Perseu Abramo, 1997, p. 47-50. 
SANTOS, Ivan (Dir.). Clara Charf: a companheira de Marighella (Documentário), 2003. Disponível em https://repositorio.ufsc.br/xmlui/handle/123456789/131873. Consulta em 14/03/2021.

SETEMY, Adrianna. "Ato sem perdão": justiça de transição, políticas de memória e reparação às mulheres vítimas de violência de gênero durante a ditadura militar brasileira. Estudos Históricos. Rio de Janeiro, v. 33, n. 70, p. 338358, Agosto 2020.

SILVA, Cristiani Bereta da. O saber histórico escolar sobre as mulheres e relações de gênero e nos livros didáticos de história. Caderno Espaço Feminino, v. 17, n. 01, Jan./Jul. 2007, p. 219-246.

SILVA, lara Augusta da. O Programa Nacional do Livro Didático para o Ensino Médio (PNLD/EM): uma política Nacional implementada pelo estado brasileiro no início do século XXI. 2015. In: 37ạ Reunião Nacional da Associação Nacional de Pós-Graduação e Pesquisa em educação (ANPED). Disponível em: https://anped.org.br/biblioteca/item/o-programa-nacional-do-Livro-didaticopara-o-ensino-medio-pnldem-uma-politica-de. Consulta em 19 de outubro de 2020.

SILVA, Marcelo Soares Pereira. O livro didático como política pública: perspectivas históricas. In: ROCHA, Helenice; REZNIK, Luis; MAGALHÃES, Marcelo de Souza (orgs.). Livros Didáticos de História: entre políticas e narrativas. Rio de Janeiro: FGV editora, 2017, p. 101-120.

SILVA, Tauana Olívia Gomes. Mulheres negras nos movimentos de esquerda durante a ditadura militar no Brasil (1964-1985). Florianópolis: UFSC, 2019. Tese de doutorado em História.

SIRKIS, Alfredo. Os Carbonários. São Paulo: Global, 1980.

SOIHET, Rachel; PEDRO, Joana Maria. A emergência da pesquisa da História das Mulheres e das Relações de Gênero. Revista Brasileira de História. São Paulo, v. 27, no 54, p. 281-300, 2007.

SOUSA, Deusa Maria de. Lágrimas e lutas: a reconstrução do mundo de familiares de desaparecidos políticos do Araguaia. Florianópolis: UFSC, 2011. Tese de doutorado em História.

SOUSA, Deusa Maria de. Militância, família, partido: o caso do Araguaia. In: Anais do Seminário Fazendo Gênero 10. Florianópolis: UFSC, 2013. Disponível em http://www.fg2013.wwc2017.eventos.dype.com.br/resources/anais/old 20/13735 02892 ARQUIVO DeusaMariadeSousa doc.pdf. Acesso em 19 de março de 2021.

TAVARES, Flávio. Memórias do esquecimento: os segredos dos porões da ditadura. Porto Alegre: L\&PM, 2012. 
TELES, Janaína de Almeida. Entre o luto e a melancolia: a luta dos familiares de mortos e desaparecidos políticos no Brasil. In: SANTOS, Cecília Macdowell; TELES, Edson; TELES, Janaína de Almeida (Orgs.). Desarquivando da ditadura: memória e justiça no Brasil. São Paulo: Hucitec, 2009, vol. 1, p. 151-176.

VAQUINHAS, Irene Montesuma. História das mulheres. In: COLLING, Ana Maria; TEDESCHI, Losandro (Orgs.). Dicionário crítico de gênero. Dourados, MS: Ed. UFGC, 2015, p. 335-340.

VARGAS, M. C. Deslocamentos, vínculos afetivos e politicos, conquistas e transformações das mulheres opositoras à ditadura civil-militar: A trajetória do Movimento Feminino pela Anistia no Rio Grande do Sul (1975-1979). 2010. 320 f. Dissertação (Mestrado em História) - Universidade Vale do Rio dos Sino, São Leopoldo, RS, 2010.

VIANNA, Martha. Uma tempestade como a sua memória: a história de Lia, Maria do Carmo Brito. Rio de Janeiro: Record, 2003.

WOLFF, Cristina Scheibe. O gênero da esquerda em tempos da ditadura. In: 138154. In: PEDRO, Joana Maria; WOLFF, Cristina Scheibe (Orgs.). Gênero, feminismos e ditaduras no Cone Sul. Florianópolis: Editora Mulheres, 2010.

WOLFF, Cristina Scheibe; MACHADO, Vanderlei. Gênero e Militância de Esquerda. In: Ana Lice Brancher; Reinaldo Lindolfo Lonh. (Org.). Histórias na ditadura Santa Catarina (1964-1985). 1ed.Florianópolis: Editora UFSC, 2014, p. 159-180.

Universidade do Estado de Santa Catarina - UDESC

Programa de Pós-Graduação em História - PPGH

Revista Tempo e Argumento Volume 13 - Número 34 - Ano 2021 tempoeargumento.faed@udesc.br 